\title{
Pamela McElwee és szerzőtársai* Hogyan birkózhat meg a COVID-19 utáni gazdaságpolitika a biológiai sokféleség csökkenésével?
}

A COVID-19 járvány világszerte olyan károkat okozott a gazdaságban, amilyenekre egy jó emberöltő óta nem láttunk még példát. A karanténszabályok bevezetése, a nemzetközi utazások visszaesése és a közösségi tevékenységek korlátozása csapásként érte a mindennapi gazdasági kapcsolatokat. A járvány miatt súlyos károkat elszenvedő fejlett gazdaságok közül többen, például az Egyesült Államok és az Európai Unió számos országa, nagy léptékü beruházásokat és gazdaságélénkítő kormányzati intézkedéseket kezdett bevezetni, hogy útját állja a növekvő munkanélküliségnek és a pénzügyi összeomlásnak. Sokan a „normálishoz” való visszatérésre tett kísérletként értelmezik ezeket az intézkedéseket, s arról beszélnek, hogy a mentőcsomagokkal „visszatereljük a gazdaságot a rendes kerékvágásba”. A Biológiai Sokféleség és Ökoszisztéma-szolgáltatás Kormányközi Testület (IPBES) által nemrégiben közzétett, a bolygónk egészségügyi állapotáról szóló felmérés azonban, csakúgy, mint több más nemzetközi intézet, arra figyelmeztet, hogy a „normális”, pandémia előtti gazdasági ügymenethez való visszatérés nem elfogadható, hiszen az aláássa az emberiség és az egész bolygó jövőbeli jóllétét [1].

Az ökoszisztémák és a biológiai sokféleség elmúlt ötven évben megtapasztalt gyors állapotromlása hatalmas nyomás alá helyezte azokat a természeti rendszereket, amelyek élelmiszert, vizet és más haszonvételeket biztosítanak az emberiség számára [2]. Az IPBES Globális Felmérése, amely 2019 májusában jelent meg, a természetben zajló negatív folyamatokat közvetlen hatótényezőkhöz - így a föld- és tengerhasználatban bekövetkező változásokhoz (elsősorban a mezőgazdaság terjeszkedéséhez), a vadon termő fajok túlhasználatához, a klímaváltozáshoz, az idegenhonos fajok terjedéséhez és a szennyezéshez - kapcsolta, amelyek mindegyike maga is

\footnotetext{
* Pamela McElwee, Esther Turnout, Mireille Chiroleu-Assouline, Jennifer Clapp, Cindy Isenhour, Tim Jackson, Eszter Kelemen, Daniel C. Miller, Graciela Rusch, Joachim H. Spangenberg, Anthony Waldron, Rupert J. Baumgartner, Brent Bleys, Michael W. Howard, Eric Mungatana, Hien Ngo, Irene Ring és Rui Santos: Ensuring a post-COVID economic agenda tackles global biodiversity loss. One Earth 3 (4), 2020. október 23., 448-461. (C) 2020 Elsevier Inc. Kelemen Eszter fordítása. A fordításban közremüködött: Kocsis Tamás, Málovics György és Pataki György. (Magyar nyelven megjelent: 2021.03.22.)
} 
számos közvetlen hatótényezőtöl, például demográfiai és társadalmi folyamatoktól és gazdasági érdekektől függ [1]. Főként a globális gazdaság növekedett hirtelen gyorsasággal az elmúlt fél évszázadban. A tőkefelhalmozás és a kereskedelem korszakunkban egyre fokozódó mértéke földrészeken átívelő, környezeti-társadalmi-gazdasági kölcsönhatásokhoz (telecoupling) és tovagyürüző nem várt következményekhez (spillover) vezetett [3], továbbá a természetes élőhelyek olyan, nagy kiterjedésű pusztulását okozta, amely összefüggést mutat a COVID-19-hez hasonló új vírusok megjelenésével (1. ábra) [4]. Régóta ismert, hogy az ökológiai rendszerek állapotromlása jelentős kockázatot hordoz, mivel aláássa azokat a természeti erőforrásokat, amelyekre gazdasági folyamataink épülnek. A COVID-19 megjelenése előtt azonban ezek a kockázatok sokak számára távolinak és valószínütlennek tüntek [5].

Most válaszúthoz érkeztünk. Nem csak a járvány okozta rövid távú gazdasági hatásokat kell orvosolnunk, de arról is el kell gondolkoznunk, hogy milyen gazdaságot szeretnénk - és milyen gazdaságra van szükségünk -, ha a jövőben egy fenntarthatóbb, igazságosabb és egyenlőbb kapcsolatokon alapuló világban szeretnénk élni. A gazdaságot a helyes pályára visszaterelni igyekvő, gyorsszerviz jellegü beavatkozások valószínüleg nem képesek kezelni azokat a mélyen gyökerező fenntarthatósági és igazságossági problémákat, amelyek megoldása a természetről való gondoskodást és az igazságosság szempontjainak figyelembevételét követelik meg. Kutatások szerint az Egyesült Államok és az Európai Unió lakosainak nagy része egyetért azzal, hogy a poszt-COVID világnak olyan új értékrendet kell tükröznie, amely a természet megóvását, a klímaváltozás kezelését és a társadalmi egyenlőséget is magában foglalja [6].

Miközben sok tudós és politikus érvel amellett, hogy a pandémia utáni gazdasági kilábalást minél alacsonyabb szén-dioxid-kibocsátás mellett kell megvalósítani [7], sokkal kevesebb figyelem irányul arra, hogy miként lehet a biodiverzitás és az ökoszisztémák megőrzésének szempontjait integrálni a gazdaság átalakításába. A világjárvány kapcsán megfogalmazott, természethez kapcsolódó intézkedések eddig föként az állatokról emberekre átterjedő vírusok elsődleges forrásának tartott vadállat-piacok bezárására, a védett területek kiterjesztésére, illetve a trópusi területeken zajló erdőirtások visszaszorítására koncentráltak [4, 8, 9]. Bár ezek valóban fontos akciók, nem igazán képesek a problémák mélyére hatolni és kezelni azokat a háttérben müködő hatótényezőket, amelyek a gazdasági kereslet növekedését és az ökológiai állapotromlást elsősorban kiváltják. A gazdasági mentőcsomagok többségében nem kaptak prioritást azok a konkrét szak- 


\section{Kormányzati fiskális Piacok és politika és ktgvetés gazdasági növekedés}

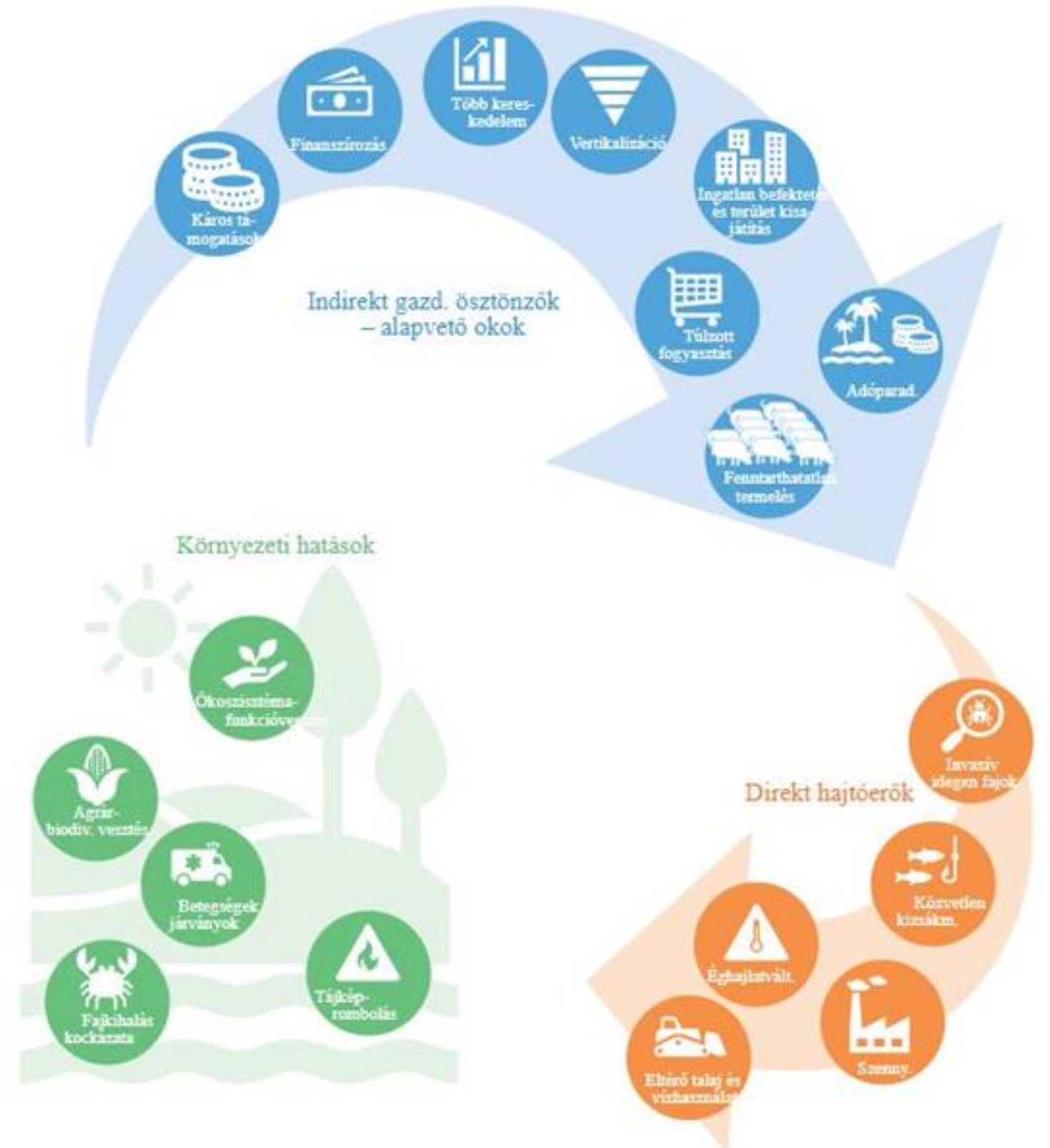

1.ábra A biodiverzitás csökkenésének és az ökoszisztémák átalakulásának fő mozgatórugói

(Az IPBES Globális Felmérése öt fö közvetlen hajtóerőt azonosított, amelyek a következö ötven évben jelentősen befolyásolják az ökoszisztémák állapotát /narancssárga körök/, számos környezeti hatást elindítva /zöld körök/. A Globális Felmérés az egyik legföbb közvetett hajtóeröként határozta meg a gazdaság természetre gyakorolt nyomását. Az ábra kék körökben mutatja a gazdasági keresletben és kínálatban zajló változásokat, amelyek az ökoszisztémák leromlását okozzák.) 
politikai intézkedések, amelyek a biodiverzitás védelmét és az ökoszisztémák hosszú távú használatát tüzik ki célul; még azok a programok is, ahol megjelentek ökológiai szempontok, többnyire a klímaváltozás hatásait ellentételező vagy enyhítő intézkedésekre szorítkoztak. Csupán néhány ország illesztett be olyan beruházásokat és ösztönzőket a gazdaságélénkítő programjába, amelyek a természeti környezetre alapoztak (2. ábra), és még ezekben az esetekben is jóval a teljes mentőcsomag értékének $10 \%$-a alatt maradt a természetvédelemre fókuszáló intézkedések nagyságrendje [10]. Több olyan ország is van, például az Egyesült Államok és Kína, ahol valójában nulla a biodiverzitásra és ökoszisztémákra irányuló élénkítő beavatkozások értéke.

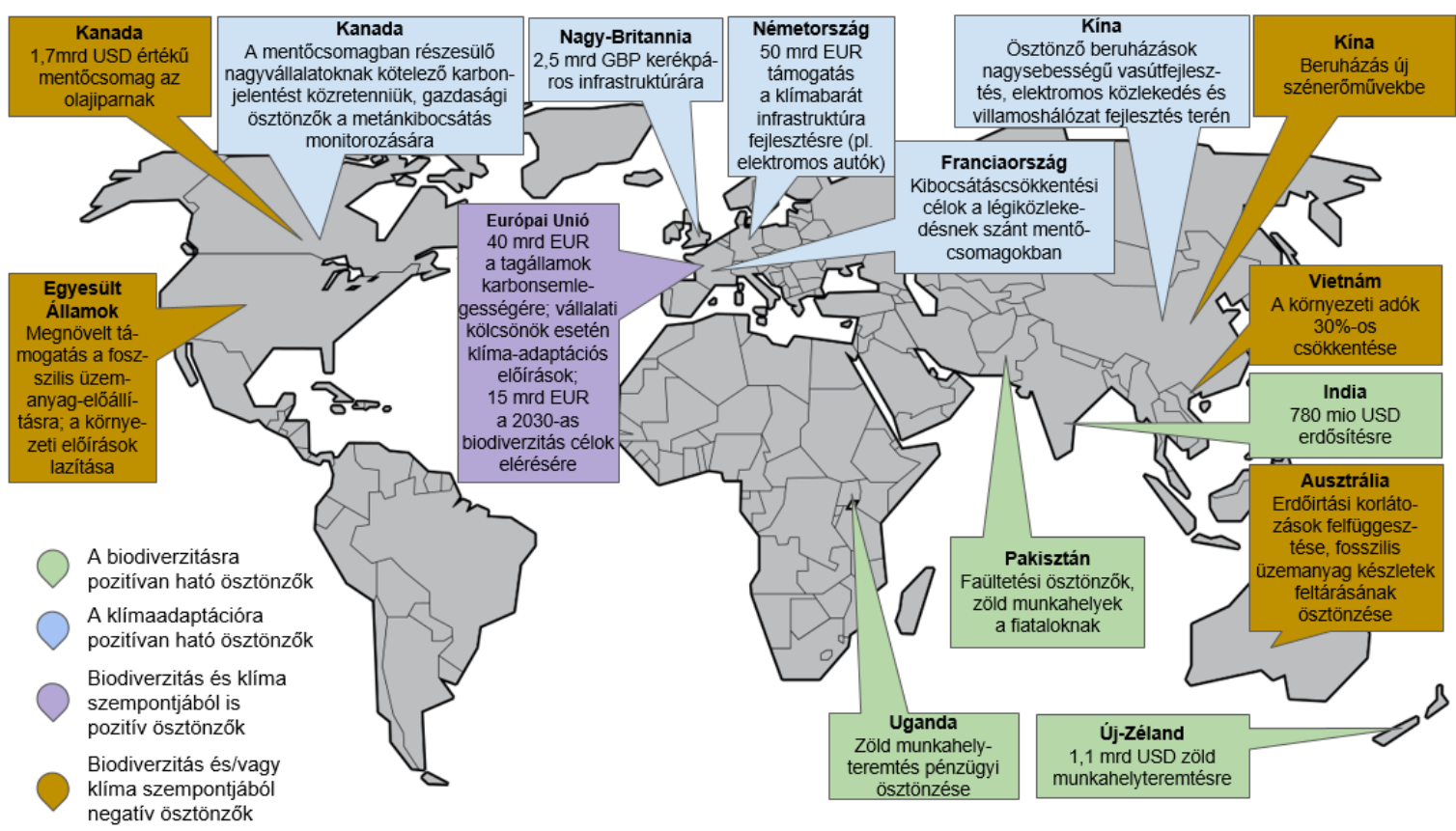

2. ábra A COVID-19 járvány során bevezetett gazdaságélénkítő intézkedések (2020. szeptember 15-ig számos kormány vezetett be vagy tett javaslatot gazdaságélénkitő és -mentő csomagokra a COVID-19 járvány hatásait ellensúlyozandó. Csak néhány ország integ-

rálta a klímaváltozás vagy a biodiverzitás-csökkenés hatásait ellensúlyozó intézkedéseket a gazdaságélénkitő intézkedésekkel, és több helyen vezettek be olyan csomagokat, amelyek környezetre gyakorolt hatásai károsak /például a környezeti adók csökkentése vagy a szabályok lazítása/. További információ néhány kiválasztott ország gazdaságélénkítő csomagjairól angol nyelven olvasható a hivatkozások között felsorolt nyilvános adatbázisokban. *)

\footnotetext{
*A 2. ábra térképén a jelenleg létező és javasolt COVID mentőcsomagokról
} rendelkezésre álló adatok a következő weboldalakon közzétett adatbázisokból 
Számos olyan szakpolitikai intézkedés és ösztönző létezik, amely segítheti a gazdaság újjászervezését, miközben képes orvosolni a biodiverzitás csökkenését előidéző okokat, és a zoonózisok ${ }^{*}$ előfordulásának a lehetőségét is mérsékelheti. Még a legrosszabb esetben is elvárható lenne, hogy a mentőcsomagok ne ártsanak az ökológiai rendszernek, de ambiciózusabb és hosszabb távú intézkedésektől akár a globális gazdaság átalakulását is remélhetnénk, amely megoldást kínál a biodiverzitás, a klímaváltozás és az emberi jóllét egymással összefüggő kihívásaira. Tanulmányunkban újragondoljuk az IPBES Globális Felmérés részeként közölt idevágó elemzéseket, és olyan javaslatokat fogalmazunk meg, amelyek segíthetik a gazdasági folyamatok, politikák és intézmények transzformációját. Úgy gondoljuk, e transzformáció által csökkenhet a természeti rendszerekre nehezedő nyomás, és végbemehet egy fenntartható átalakulás, amely végső soron a COVID-19-hez hasonló világjárványok kialakulásának valószínüségét is csökkenti. $A z$ általunk kínált eszköztár olyan intézkedéseket foglal magában, amelyek különböző kontextusokban - többféle szereplő közremüködésével - potenciálisan megvalósíthatók. Nem ígérjük, hogy bármely ország, bármely helység vagy bármely vállalat képes lehet az összes itt bemutatott eszközt bevetni. Inkább arra szeretnénk rámutatni, hogy igenis léteznek olyan opciók, amelyek révén gazdaságunk újrastrukturálható és életképessé tehető, ökológiailag fenntartható módon is (Függelék, 1. táblázat).

\section{Azonnali szükségletek és rövid távú prioritások}

\section{Elmozdulás a környezeti szempontból ártalmas támogatásoktól a hasznos támogatások felé}

Növekvő költségvetési veszteségek idején a környezeti szempontból ártalmas támogatások sem gazdasági, sem ökológiai szempontból nem indokolhatók. 2015-ben csak az OECD** országokban meghaladta a százmilliárd dollárt a természeti környezet számára ártalmas mezőgazdasági támogatások értéke, míg a fosszilis üzemanyagokra szánt támogatások - amelyek nem csak a légkörbe kerülő szén-

származnak: https://www.imf.org/en/Topics/imf-and-covid19/Policy-Responsesto-COVID-19, https://www.carbonbrief.org/coronavirus-tracking-how-the-worldsgreen-recovery-plans-aim-to-cut-emissions,

https://www.energypolicytracker.org/region/g20 és

https://www.climateinteractive.org/ci-topics/great-recovery-policies.

A pénzösszegek ebböl az adatbázisból származnak:

https://doi.org/10.17632/whf4hkfwdx.1, valamint a függelék 2. táblázatából.

*Állatok közvetítésével kialakuló humán betegségek. ( $A$ ford.)

** Gazdasági Együttmüködési és Fejlesztési Szervezet ( $A$ szerk.) 
dioxid mennyiségét növelik, de szennyezik a vízbázist és a termőföldet a kitermelés, a feldolgozás és a tárolás helyszínén - éves szinten és globálisan 200 és 680 milliárd $\left(10^{9}\right)$ dollár között mozognak, az általuk okozott károk becsült értéke pedig eléri a 4 billió $\left(10^{12}\right)$ dollárt, messze meghaladva a támogatásoknak köszönhető gazdasági elönyöket $[11,12,13]$. A kormányok által a saját felségjelük alatt hajózó halászflottáknak nyújtott támogatás éves szinten mintegy 35 milliárd dollárra rúg, amely a legtöbb esetben túlhalászatra ösztönöz és meghaladja a halászat nettó gazdasági bevételeit [14]. Összességében, a biodiverzitás védelmére mozgósított pénzügyi forrásokat konzervatív becslések szerint is legalább tízszeresével múlja felül a környezeti szempontból ártalmas támogatások mértéke [11].

A támogatások önmagukban véve nem feltétlenül károsak. Ezek olyan eszközök a kormányok kezében, amelyek révén az ökoszisztémák egészséges működését lehetővé tevő beruházások megvalósíthatók. Ugyanakkor a támogatások eredeti céljai, mint a gazdaság életképességének megőrzése vidéken vagy az új iparágak betelepítése, legtöbb esetben éppoly hatékonyan elérhetők a közjavak támogatása révén, mint a túlhasználat ösztönzésével. A támogatáspolitika reformja gyakran az összefonódó érdekeltségek miatt lehetetlenül el [15], például az olajpiacokon jelenleg tapasztalható zürzavar még fokozta is a fosszilis üzemanyagok támogatásáért folytatott lobbitevékenységet, ahelyett, hogy a támogatások megszűnését eredményezte volna. Azok a kutatások, amelyek az eddig mindössze néhány országban bevezetett támogatáspolitikai reformokat vizsgálták, öt fő megállapítással szolgáltak: (1) gyorsan kell cselekedni, amikor olyan lehetőség nyílik, ami kívül áll a nemzeti szintü döntéshozók és környezetük hatáskörén (ilyen például a jelenlegi egészségügyi krízishelyzet), (2) szövetségeket kell kiépíteni a gazdasági és környezeti érdekek képviselöi között, (3) célzott intézkedések szükségesek a versenyképességre és a jövedelemeloszlásra gyakorolt esetleges negatív hatások ellensúlyozására, (4) megalapozott vizsgálatokat kell folytatni a reform társadalmi költségeinek és hasznainak feltárása érdekében, végül (5) széles körben kell bevonni az érintetteket a reformfolyamatba [16].

Ismerünk jó példákat is a biológiai sokféleségre pozitív hatást gyakorló támogatásokra, amelyek továbbfejlesztésre és szélesebb körü alkalmazásra érdemesek. Ilyenek a gazdálkodóknak nyújtott, az ökoszisztémák egészségének megőrzésére ösztönző földhasználati támogatások, amelyek mind az Egyesült Államok, mind az Európai Unió mezőgazdasági politikájában megtalálhatók. Mindkét esetben igaz azonban, hogy a környezeti szempontból kedvező agrártámogatási elemek finanszírozása (például a természetvédelmi célokra 
elkülönített területek, a biogazdálkodásra és integrált gazdálkodásra fordított támogatások vagy a magas természeti értékü területek rendszere) elmarad a többi agrártámogatási forrástól, amelyek túltermeléshez, a mezőgazdaság fokozódó térnyeréséhez és az állattartás intenzívebbé válásához, s ezen keresztül az üvegházhatású gázok kibocsátásának növeléséhez vezetnek $[17,18]$. Kutatások szerint az agrártámogatások környezeti hasznainak kiaknázása akkor a leghatásosabb, ha a támogatások célzottan a biodiverzitásban gazdag területekre irányulnak és ott gátolják a termelésbe vont területek arányának növelését, valamint ösztönzik az ökológiai szempontból legértékesebb gyakorlatokat azok eredményalapú finanszírozásán keresztül, szemben a jelenlegi gyakorlattal, amikor a támogatások nagy része önként jelentkező gazdákhoz vagy nagygazdaságokhoz kerül $[19,20]$.

A közpénzekböl finanszírozott támogatások másik típusa a zöld közbeszerzés, ami hatékonyan ösztönözheti a biodiverzitás-fókuszú élelmiszer-előállítást. Éppúgy, ahogy a kormányok által generált kereslet felpörgette az orvosi eszközök és kiegészítők gyártását, amely nélkülözhetetlen a COVID-19 járvány kezeléséhez, a természetbarát módon megtermelt élelmiszerek közösségi beszerzése a fenntarthatóan előállított élelem helyi előállítására ösztönözhet és növelheti a beruházási volument [21, 22]. Miközben komoly viták zajlanak arról, hogy a biogazdálkodás és más környezetkímélő termelési módszerek tényleg alacsonyabb hozamokat eredményeznek-e, s ezáltal kockáztatják-e a termelésbe vont területek növelését, egyre több kutatási eredmény bizonyítja, hogy a tudásintenzív földhasználati gyakorlatok, amelyek egyszerre építenek az ökoszisztéma-szolgáltatásokra és segítik azok fennmaradását, valóban képesek egészséges, fenntarthatóan és megfizethetően termelt táplálék előállítására, ha más intézkedésekkel - például a hús- és tejtermékfogyasztás mérséklésével kombinálják őket $[23,24]$. Az intenzívebb gazdálkodás fenntartható módszerei kontextusfüggők, és magukba foglalják a precíziós mezőgazdaságot, a kártevők biológiai kontrollját vagy integrált kezelését, az ökológiai infrastruktúra fejlesztését (például táblaszegélyek kialakítását vagy permakultúrás gazdálkodást) és a faji sokféleséget tükröző agrár-erdészeti vagy agrár-legeltetéses rendszerek kialakítását. Mindegyik felsorolt módszerben közös, hogy az agrár-ökológiai funkciók javítását célozzák, többek között a tápanyag-körforgás, a talajmegőrzés és a biodiverzitás (főként a beporzók és a talajélővilág) védelmén keresztül [25]. 
Az adózási politika továbbfejlesztése és kiterjesztése a környezetkárositó tevékenységekre

A környezetpolitikában hosszú múltra tekintenek vissza a környezetvédelmi adók és díjak (például az üzemanyag vagy a müanyag zacskók árában foglalt termékdíjak), amelyek a szennyezés csökkentésére és az erőforrás-használat hatékonyságának növelésére irányulnak. Ezzel szemben nagyon kevés fogyasztási adót vagy közvetlen díjat ismerünk, amelyet kifejezetten a biodiverzitás védelme céljából vezettek be. A legtöbb adófajta, amit az ökoszisztémákra és a biodiverzitásra negatív (és gyakran közvetett) hatást gyakorló tevékenységekre vagy termékekre vetnek ki, a „szennyező fizet” vagy a „fogyasztó fizet" elvet követi azzal a céllal, hogy bizonyos fogyasztói magatartásokra ösztökéljen, de az esetek többségében a viselkedésváltozás igen mérsékelt marad, s így a negatív környezeti hatások sem csökkennek érdemben [26]. Egy jól megtervezett termékárazási mechanizmus fogyasztói ösztönzőként hat, ráadásul bevételként szolgál a kormányzat számára helyi, regionális vagy országos szinten [27]. Ökoszisztéma-alapú adók széles körét lehetne bevezetni és kiterjeszteni, többek között a természeti erőforrások kitermelésére (például fakitermelésre), növényvédőszer-használatra, diffúz (térben szétszórt) szennyezésre (például vízszennyezéshez kapcsolódó díjakat), légszennyezésre és üzemanyag-használatra (amennyiben elfogadjuk, hogy a levegőszennyezés a savasodáson és elmocsarasodáson keresztül károsítja az ökoszisztémákat), szén-dioxid-kibocsátásra (ún. szénadót) vagy hulladékkezelésre és csomagolásra [28]. A szénadó emelésének franciaországi esete ugyan elbátortalanító lehet - hiszen ott a szén-dioxid-kibocsátásra kivetett adó emelése széles körű tiltakozást váltott ki, és összekapcsolódott a sárgamellényes mozgalommal -, nagyobb társadalmi elfogadottságot lehet elérni, ha az adózási mechanizmus követi a társadalmi igazságosság szempontjait, és garantálja, hogy az adóteher ne sújtson igazságtalanul nagyobb mértékben bizonyos társadalmi csoportokat [29]. Megoldást jelenthet például, ha a karbondíjat vagy szénadót háztartásoknak nyújtott osztalékkal vagy engedménnyel kombinálják, hiszen az alacsony és közepes jövedelmű családok többsége végül több pénzt kapna vissza, mint amennyit befizetne egy progresszív adózási rendszerben [30]. Másutt azt is láthatjuk, hogy a szénadó közvetlenül használható természetvédelmi intézkedések finanszírozására, például Costa Ricában az üzemanyagadóból befolyó összegekből erdővédelmi programokat finanszíroznak [31].

A köznevelési és szemléletformálási programok nélkülözhetetlenek ahhoz, hogy a társadalom széles rétegei megértsék: a környe- 
zetvédelmi adók olyan ösztönzök, amelyek mérhetö környezeti hasznokat eredményeznek, és nem csupán az állami költségvetésben keletkező lyukak betömését szolgálják. A pszichológiai hatásokat nem szabad alábecsülnünk. Az egyik ígéretes megközelítés, amelynek hatékony ösztönző hatása jól bizonyított, a kötelező felelősségbiztosításokból ismert „bónusz-malusz” rendszer, amely a negatív viselkedést adóval vagy növekvő díjakkal bünteti, míg a pozitív viselkedést engedményekkel jutalmazza. Franciaországban 2009-től kezdődően vezettek be bónusz-malusz rendszert az autóvásárlásokra az eladott autók szén-dioxid-kibocsátásával arányosan, amelynek hatására növekedésnek indult a kevesebb lóerővel működő autók eladása, és annál is nagyobb mértékben esett vissza a sok lóerős járművek értékesítése [32]. Az ötlet adaptálható volna kiegyensúlyozott költségvetésü „ökológiai bónusz-malusz” programokra, amelyek büntetnek vagy jutalmaznak a biodiverzitásra gyakorolt hatás függvényében [33]. Aggodalmat keltő ugyanakkor, hogy a pandémiára válaszul meghirdetett gazdaságélénkítő csomagok egy része, ahelyett hogy a környezetkárosító iparágak megadóztatásának vagy innovatív finanszírozásának lehetőségeit keresné, épp ellentétes irányba mozdul el az adók és a környezetvédelmi előírások mérséklésével. Ez a gazdaságot rövid távon stimuláló stratégia valószínüleg számos negatív egészségügyi és környezeti következménnyel jár majd hoszszabb időtávon (2. ábra és Függelék, 2. táblázat) [34].

Szűk esztendőkben a kormányok előtt álló további lehetőség az adóparadicsomok felszámolása és a bevételek országhatárokon belül tartása. Az offshore bevételek és eltitkolt számlák csökkentik a kormányok pénzügyi mozgásterét és behatárolják a közösségi szolgáltatásokra fordítható összeget, miközben lehetőséget nyitnak a „rosszfiúknak” a pénzügyi felülvizsgálat elkerülésére, és csökkentik a minősítéseken és ellátásilánc-felügyeleten alapuló intézkedések hatásosságát. Egy friss kutatás szerint az illegális halászatban érintett halászhajók 70\%-a adóparadicsomok zászlója alatt hajózik, míg az Amazonas vidékének legnagyobb szójatermesztő és szarvasmarhatartó társaságai - amelyek a trópusi esőerdők pusztulásának elsődleges felelősei - adóparadicsomokon keresztül kapták külföldi tőkeutánpótlásuk 70\%-át [35]. Elképzelhetőnek tartjuk, hogy a kormányok megakadályozzák, hogy az adóparadicsomokon meggazdagodó vállalatok további hasznot húzzanak a közpénzek terhére a COVID-19 mentőcsomagok révén. 


\section{A gazdaság újraélesztése a természetvédelem támogatása és a környezeti károk csökkentése révén}

Rövid távon, mivel a magánszektornak finanszírozási forrásokra van szüksége, hogy fedezni tudja a bérköltségeket és megőrizze az életképességét a jövőre nézve is, a kormányok előnyben részesíthetik azokat a szektorokat és vállalatokat a támogatások szétosztásánál, amelyek nem károsítják a természeti környezetet, és szigorításokat várhatnak el a termelésben a beruházások finanszírozásáért cserébe. Például a 2008-2009-es amerikai autóipari mentőcsomag következményeként az Obama kormányzat elegendő befolyásra tett szert ahhoz, hogy az autógyártókkal közösen szigorúbb (gazdaságosabb fogyasztást garantáló) üzemanyag-fogyasztási elöírásokat dolgozzon ki, majd a 2009-ben elfogadott Amerikai Válságkezelési és Refinanszírozási Törvény számos formában biztosított kölcsönt és adójóváírást a zöldebb jármüvek fejlesztéséhez [36].

A COVID-19 mentőcsomagokból részesülő vállalatok számára is lehetne hasonló stratégiát előírni, amely tartalmazhatná a biodiverzitásra gyakorolt kockázatok elkerülésének tervét, kérhetné a környezeti hatások nyilvánossá tételét, vagy megkövetelhetné a környezeti szempontok vállalati döntéshozatalba való integrálását, különösképpen olyan iparágakban, amelyek igazoltan nagymértékben alakítják át a természeti környezetet (ilyenek például az agrár-, ruhaipari, bányászati és energetikai vállalatok) [37]. A feltételhez kötött támogatások kiterjeszthetők lennének a tengerjárókra (a támogatásért cserébe elvárva, hogy jelentősen mérsékeljék az óceánokra gyakorolt szenynyező hatásukat) [38], továbbá a légitársaságokra, akik - a rendelkezésükre bocsátott közpénzekért cserébe - csökkenteni kényszerülnének szén-dioxid-kibocsátásukat (ez már jelenleg is elvárt Franciaországban). Kanada a nagyvállalatoknak nyújtott pénzügyi segítség feltételéül szabja, hogy e cégek megadott sztenderdek szerint beszámoljanak szén-dioxid-kibocsátásuk alakulásáról. Az Európai Unió pedig „a negatív környezeti hatások elkerülése” alapelv alapján előírja, hogy a 2021-27 közötti költségvetési időszak forrásai csak olyan fejlesztésekre és intézkedésekre használhatók fel, amelyek nem hátráltatják a környezetvédelmi prioritások teljesülését. $E$ példákat leszámítva kevés helyen találkozhatunk a pénzügyi segítségnyújtáshoz kapcsolt környezeti elöírásokkal. A feltételhez kötött támogatások rendszere átlátható kellene legyen a tekintetben is, hogy mely területekre irányulnak a pénzügyi források, hogy a nyilvánosság erejével lehessen kikényszeríteni az előírások betartását [39]. E megközelítéssel szemben kifogásként merülhet fel, hogy a mentőcsomagok feltételhez kötése jelentősen befolyásolhatja a versenyképességet, ugyanakkor maguk a mentőcsomagok is igazságtalanul hozhatnak 
helyzetbe bizonyos iparágakat másokkal szemben. A mentőcsomagok versenyképességre gyakorolt végső hatása a korlátozások és ösztönzők összjátékától függ, és észszerűnek tűnik az a feltételezés, hogy megéri vállalni a túlzó piaci előnyök bizonyos mértékü korlátozását (a pénzügyi támogatás feltételekhez kötése révén) a várható környezeti hasznokért cserébe.

\section{Ökoszisztéma-alapú foglalkoztatási programok és jövedelemtámogatás}

A gazdasági válság közvetlen utóhatásai idején a kormányok által kezdeményezett foglalkoztatási programok kulcsszerepet játszhatnak a munkanélküliség kordában tartásában, és a természetvédelem területén különösen gyorsan lehet új munkahelyeket teremteni. Épp úgy, miként a nagy gazdasági válság idején új munkahelyek ezrei jöttek létre az Egyesült Államok közmunkaprogramja és civil természetvédő alakulatai révén, most is hatalmas munkaerőt tudnának felszívni az ökológiai helyreállítással foglalkozó restaurációs projektek és zöldinfrastruktúra-fejlesztések, miközben kedvező környezeti hatásokat eredményeznének [40]. A foglalkoztatási programokat célzottan a járvány által leginkább sújtott térségekbe lehetne irányítani, például lepusztult városi ökoszisztémák helyreállításán vagy a zöldterületek fejlesztésén keresztül, így a COVID-19 által legnagyobb mértékben érintett hátrányos helyzetü - eltérő bőrszínű, kisebbségben élö, marginalizált, a faji megkülönböztetés ellen harcoló stb. társadalmi csoportokat lehetne elönybe hozni [41].

Egy friss kérdőíves kutatásban a megkérdezett közgazdászok szerint a zöld (biodiverzitásra vagy klímaadaptációra fókuszáló) gazdasági szektorokra irányuló ösztönzők esetében várhatók a legnagyobb kedvező gazdasági és társadalmi hatások mind rövid, mind hosszú távon, míg a légitársaságoknak nyújtott támogatásokat találták a legrosszabb hatásfokúnak [7]. A zöld beruházások pozitív munkaerőpiaci hatása már korábban igazolást nyert: az Egyesült Államokban 2009-ben a tengeri ökoszisztémák helyreállítására indított projektek egymillió dollárra vetítve több munkahelyet teremtettek, mint számos más iparágba irányuló befektetés (lekörözték például a fosszilis iparágak munkahelyteremtő képességét is) [42]. Egy ausztrál kormányzati háttérkutatás szerint négymilliárd ausztrál dollárnak megfelelő, természetvédelmi szektorra koncentráló munkahelyteremtő támogatással 50000 munkahelyet lehetne létrehozni [43]. Az ökoszisztéma-szolgáltatások pénzügyi ellentételezésére indított projektek eddig is számos országban generáltak új munkalehetőségeket, például az idegenhonos fajok irtása, erdőtelepítés, ökológiai restauráció és más hasonló, az ember és a természet számára egyaránt 
előnyös beavatkozások terén. Ezek a tevékenységek ráadásul gyorsan kiterjeszthetök, mivel többnyire nagyobb irántuk a kereslet, mint a rendelkezésre álló finanszírozás [44].

A pandémia lehetőséget nyitott arra is, hogy tárgyalások induljanak a feltétel nélküli alapjövedelem (FNA) sürgösségi alapon történő bevezetéséröl. Ez megvalósulhatna például úgy, hogy fejenként havi kétezer amerikai dollárt folyósít a kormányzat az állampolgároknak, amíg a járvány hatásai enyhülni nem kezdenek - így egyszerüen, bürokráciamentesen juthatna mindenki annyi pénzhez, ami elég az alapvető szükségleteinek kielégítésére [45]. Az FNA többféle módon is müködhet, de a lényege ugyanaz: társadalmi védőhálót biztosítani az emberek számára, amely gondolat még az ENSZ 2012-es riói Fenntartható Fejlődési Konferenciájáig nyúlik vissza. Az FNA a fejlödő országokban kifejezetten hasznos módja lehet a szegénység elleni küzdelemnek, amelynek tovagyürüző hatásai - például az erdőirtás csökkenése - ökológiai szempontból is előnyösek [46]. A fejlett országokban az FNA megítélése ellentmondásosabb, részben a kapcsolódó költségek miatt, részben azért, mert kedvezőbb társadalmi hatások várhatók, ha a juttatás célzott vagy feltételekhez kötött (mint például a szükségletfüggő jóléti juttatások vagy a munkanélküliségi biztosítás esetében) [47, 48].

Ami gyakran feledésbe merül e viták során, az az, hogy a feltétel nélküli alapjövedelem a biodiverzitásra is hatással lehet, igaz, az FNA környezeti hatásai egyelöre vitatottak és kevés empirikus kutatás foglalkozik velük [49]. A létszükségleteket fedező FNA megkönnyítheti az egyszerübb életmódra való átváltást és az ökológiai lábnyom csökkentését, továbbá felértékelheti a fizetetlen (gyakran nők által végzett) munkát, például a gyermeknevelést, a múvészeti és az önkéntes tevékenységeket, amelyek úgy generálnak jelentős társadalmi hasznot, hogy jellemzően alacsonyabb a szén-dioxid-kibocsátásuk, mint a fizetett munkaerőnek [50]. A „természetvédelmi alapjövedelemre” vonatkozó legújabb javaslatok azzal érvelnek, hogy a szegénység enyhítésére és a környezet védelmére irányuló célkitüzéseket integráltan lehetne alkalmazni mindazokra, akik magas természetvédelmi értékü területek közelében élnek [51]. Az FNA költségeit fedezni lehetne környezetvédelmi források, például a szénadó vagy a szenynyezési díjak újraelosztása révén, vagy a fejlődő országoknak szánt fejlesztési támogatások újratervezésével. Más kapcsolódó programok (például a feltételes készpénzátutalások) kapcsán kimutatták, hogy a közvetlen kifizetések - a kontextustól függően - pozitív és negatív irányba is megváltoztathatják a viselkedést és annak környezetre gyakorolt hatását, ezért gondosan kell őket megtervezni. Egy indonéziai feltételes készpénzátutalási program, bár nem természet- 
védelmi célokra tervezték, csökkentette az erdőirtást a program felülvizsgálati eredményei szerint [52], ugyanakkor Sierra Leone-ban egy hasonló program az erdőirtás arányának növekedésével járt [53]. Összességében a kifizetések hatékonysága - akár feltételekhez kötik őket, akár nem - attól függ, hogy megfelelő módon strukturálják-e az ösztönzőket és hogy legitimnek tekintik-e helyben a kifizetésektöl remélt környezeti elönyöket [54].

\section{Útmutatás hosszú távú gazdasági stratégiákhoz}

Hosszabb távon elkerülhetetlen, hogy a kormányzati és a piaci szereplök egyaránt elmozduljanak a fenntarthatóbb gazdaság irányába, amely képes a természetvédelmi szempontokat is integrálni. Az IPBES Globális Felmérése egy sor lehetőséget tárt fel a meglévő szakpolitikák és forgatókönyvek hatékonyságából kiindulva, hogy miként müködhet a világunk a jövőben. A jövőt illető transzformatív változások kapcsán nélkülözhetetlen pontként deklarálta, hogy „az egyenlőtlenségek csökkentését be kell építeni a fejlesztési programokba, mérsékelni kell a túlfogyasztást és a pazarlást, és kezelni kell a gazdasági tevékenységek externális környezeti hatásait, helyi és globális szinten egyaránt' [1]. A következőkben néhány kulcsfontosságú lépést mutatunk be, amelyek segítségünkre lehetnek a gazdasági rendszer transzformatív átalakítása során (3. ábra).

Rövid távú beavatkozások

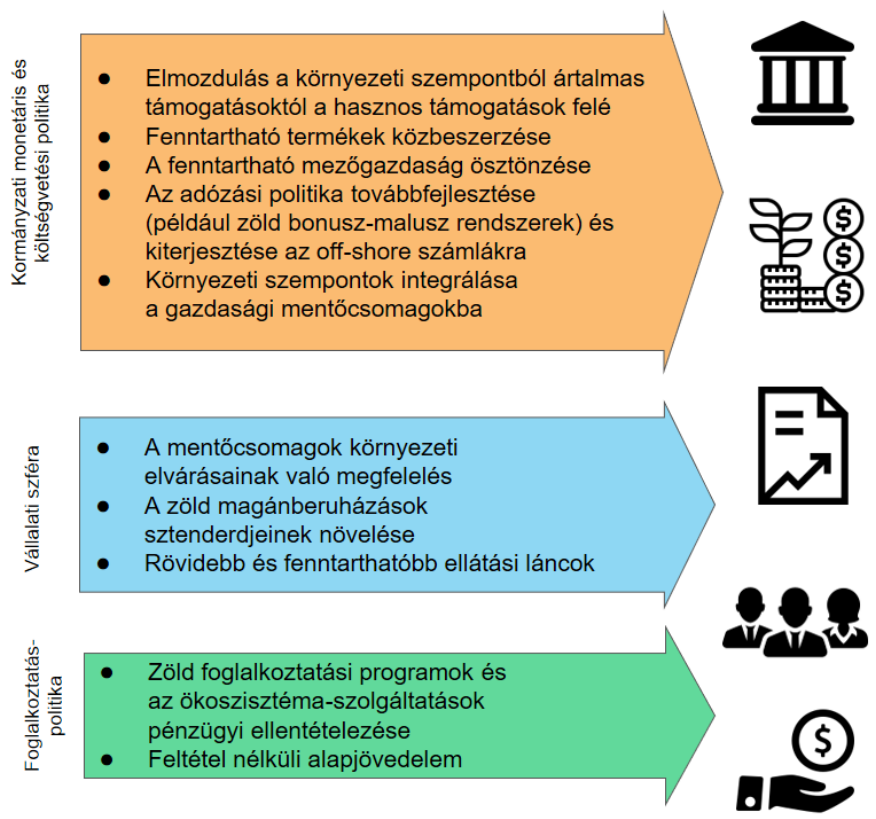

Hosszú távú intézkedések

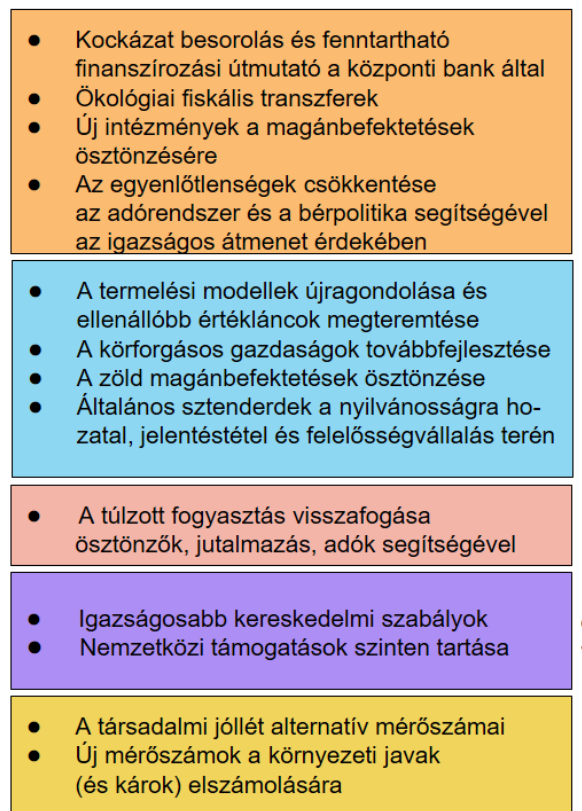

3. ábra Beavatkozási lehetőségek a globális gazdaság átalakítására a környezeti hatások mérséklése érdekében (Rövid és hosszú távú, szektorokon átívelő és minden szereplöre kitérő beavatkozásokra van szükség, hogy a globális gazdaság biodiverzitásra gyakorolt hatásait mérsékelni tudjuk.) 
A termelési és az ellátási lánc modellek újragondolása

A COVID-19 rávilágított arra, hogy a just-in-time alapú termelési rendszerek $^{*}$ igen sérülékenyek, ha a logisztikai láncolatot megszakítja egy rendkívüli esemény [55], ezért a rövid és lokalizált ellátási láncok elöretörése megkerülhetetlennek tűnik. Sokan szembesültek már azokkal a rendszerszintü kockázatokkal, amelyek a szorosan összekapcsolt, mégis törékeny ellátási láncokban rejlenek, és a túlhasznált, elszegényedő ökoszisztéma-szolgáltatásokra épülő üzletmenetet jellemzik [56]. Tekintsük például az agrárgazdasági értéklánc elmúlt néhány évtizedben lezajlott vertikalizációját! Ez a folyamat túltermelésre ösztönzött, részben a magántőke-befektetéseknek is köszönhetően, ami sok termelőt kényszerített a költségek csökkentésére. Hozzájárult továbbá a nemzetközi árutermelési egyezmények összeomlásához, amelyek még akkor is növelték a termelési volument, ha az a keresletet messze meghaladta. Végül létrehozta a jelenlegi kereskedelmi szabályokat, amelyek bebetonozzák a fenntarthatatlan beszerzési kapcsolatokat [57]. Mivel a pandémia során szerzett tapasztalatok várhatóan jelentős változásokat indítanak el a termelési rendszerekben, érdemes proaktívan elébe menni e változásoknak, és részt venni az értékláncok megreformálásában, hogy maximalizálni tudjuk a pozitív ökológiai hatásokat és minimalizálhassuk a negatív jólléti következményeket.

A globális figyelem központjában elsődlegesen az élelmiszer-termelési rendszer áll. Néhány kormány a válságra reagálva korlátozta az adott ország élelmiszerexportját és sok helyütt most próbálják helyreállítani az élelmezésbiztonságot a helyi ellátási láncok megerősítésével, amely az élelmiszer-önrendelkezéshez is hozzájárul [58]. Az élelmiszerláncok lerövidítése magában foglalja a közvetítő szereplők (például nagykereskedők, feldolgozók, szállítmányozók) számának csökkentését és a termelés és a fogyasztás közötti közvetlenebb kapcsolat kialakítását. Ez testet ölthet például közvetlen termelői-fogyasztói együttműködésekben (például gazdálkodói piacok, közösség által támogatott mezőgazdaság), közösségi élelmiszertermelésben (például közösségi kertek és magbörzék), vagy a nagyvállalati (nagytőkés) befolyás csökkenésében (például vertikálisan strukturált agrárvállalkozások helyett gazdaszövetkezetek) [59]. A fentiekhez hasonló kezdeményezések elősegítik a helyi élelmiszerrendszerek kialakulását, ahol átláthatóbb a termelés, nő a fogyasztói bizalom, javul a termékek minősége (ideértve a frissességet és az egész-

\footnotetext{
* A just-in-time rendszerek lényege, hogy a beszállított anyagok a termelési folyamat egyes szakaszaiban mindig éppen időben állnak rendelkezésre, s így a készletek minimalizálhatók. (A ford.)
} 
ségügyi hatásokat is) és csökkenthetök a káros környezeti hatások (többek között a kevesebb csomagolás, a csökkenő élelmiszer-pazarlás és a tápanyagok visszaforgatása révén, bár a szén-dioxid-kibocsátásra gyakorolt hatás továbbra is nagyon helyzetfüggő) [60].

A globális ellátási láncokról az inkább helyi léptékü termelésre való áttérés azonban kihívásokat állít a termelési rendszer hatékonysága és ellenálló képessége elé. Az átállást ezért sokféle érintett - köztük a fogyasztók - részvételével kell megtervezni. A helyi élelmiszerrendszereket vizsgáló korábbi kutatások egy része arra figyelmeztet, hogy a magasabb árak miatt csökkenő fogyasztás a jólét visszaesését is magával hozza [61], ez a szük jólétértelmezés azonban fenntarthatósági szempontból nem elfogadható. A rövidebb ellátási láncoknak vannak pénzben nem kifejezhető, a társadalom szintjén realizálható elönyei is, ideértve a város-vidék kapcsolatok revitalizációját, a gondoskodás, a kulturális beágyazódás és a helyi identitás felértékelödését [62]. Globális kereskedelemre továbbra is szükség lesz, hiszen sok régióban nem lehet helyben előállítani elegendő élelmiszert [63]. A kereskedelmi megállapodások megreformálása azonban támogathatja a rövid ellátási láncokat, különösen, ha a kereskedelmi liberalizáció helyett a méltányosság, az egyenlő hozzáférés és a fenntarthatóság felé mozdítja a rendszert, és nagyobb mozgásteret biztosít a kormányoknak a helyi termelési rendszerek priorizálásában és támogatásában [64]. A Világkereskedelmi Szervezetben zajló munka a gazdasági szempontból torzító hatású támogatások megszüntetését célozza meg. Ez kiegészíthető lenne egy valóban „zöld” támogatási csomaggal, amely ösztönzi a biodiverzitást előtérbe helyező termelést és felszámolja az ökológiai szempontból ártalmas támogatásokat, valamint a kereskedelem által felpörgetett túltermelést. Egyéb kereskedelmi reformok is elképzelhetők lennének, például az Európai Unió által fontolóra vett szén-dioxid-határadó (amellyel meg lehetne akadályozni a szén-dioxid-kibocsátás kiszervezését más, a kibocsátás mértékét illetően engedékenyebb régiókba), vagy ehhez hasonló kísérletek a zöld ellátási láncok esetében, amelyek minimalizálják a termőföldhöz kapcsolódó kibocsátást és védik a biodiverzitást [65]. A globális termelés és kereskedelem reformja azt is megköveteli, hogy a multinacionális vállalatok szakítsanak osztalékmaximalizáló gyakorlatukkal, amely sok esetben hozzájárul a túlzott mértékü és fenntarthatatlan termeléshez [66].

\section{A túlzó fogyasztás mérséklési lehetőségeinek újragondolása}

A fenntarthatatlan termelés fő mozgatórugója maga a fogyasztás. Az IPBES Globális Felmérés állítása szerint az országok megtehetik, hogy „szigorítják azokat a szennyezési határértékeket és környezet- 
védelmi szabályokat, amelyeknek a célja a gyártási folyamatok, az erőforrás-kitermelési eljárások és a fogyasztás externális hatásainak internalizálása (például a hulladékokat és szennyezést okozó termelési módok megdrágítása, beleértve a megemelt bírságok kiszabását is). Ugyancsak módjukban áll az erőforrás-hatékonyság támogatása, a piaci ellátási láncok önkéntes környezetvédelmi és társadalmi tanúsitásának terjesztése, valamint a fenntarthatóságot célzó termelési és fogyasztási gyakorlatok és innovációk ösztönzése" [1]. A COVID-19 járvány talán fölgyorsíthatja azokat a trendeket, amelyek a fogyasztás csökkenését eredményezik, hiszen a járvány idején óriási mértékben visszaestek az utazások és sokan újragondolják azt is, mit is jelent a jó életminöség [67]. Ezzel szemben számos olyan gazdaságösztönzési lépést vetettek föl (például az általános forgalmiadó csökkentését), melyek éppen a fogyasztás további növelését célozzák, anélkül, hogy számolnának a bekövetkező ökológiai hatásokkal (2. ábra, függelék 2. táblázat).

A túlzó fogyasztás mérséklésének érdekében egyaránt tehetünk lépéseket az ösztönzés és a szabályozás területén. A fogyasztói magatartás befolyásolható többek között oktatási programokkal, a fogyasztói döntési szituációk keretének megváltoztatásával, a közösségi megoldásokon alapuló fogyasztás (például megosztás, újrahasználat) terjesztésével, az erőforrás-használat mennyiségi korlátozásával, adókkal és a támogatások megváltoztatásával, hogy ez utóbbiak ne a túlzó fogyasztásra sarkalljanak [68, 69]. A „szabad egyéni döntések” mantráját valószínűleg át kell alakítanunk az „ökológiai határokon belül szabadon élvezett jó életminőség" mantrájára annak érdekében, hogy a fenti változásokat a fogyasztásban elérhessük. Kevés esély van arra, hogy a túlzó fogyasztás korlátozása általános egyetértésre talál. Ugyanakkor egyre nagyobb politikai figyelmet kapnak azok a javaslatok, amelyek a gyakorlatban alkalmazhatóvá teszik az olyan tudományos koncepciókat, mint a „fogyasztási folyosók” és a „fánk közgazdaságtana" [70]. A körkörös gazdaság és az eröforráshasználatról, illetve a gazdasági növekedésröl történő lekapcsolódás ugyancsak egyre népszerübb vita- és kutatási témák, de még ezeket sem alkalmazzák széles körben a gyakorlatban [71]. Néhányan abban bíznak, hogy az egyes gazdasági szektorokon belül bekövetkező átalakulás az erőforrás-igényes termelési módokról a szolgáltatás- és

\footnotetext{
A fogyasztási folyósók (consumption corridors) és a fánk közgazdaságtan (doughnut economy) fogalma egyaránt arra utal, hogy a fogyasztás és a gazdasági működés fenntartható keretek között tartásához alsó és felső határok meghatározására egyaránt szükség van. Az alsó határt a minden ember számára biztosított méltó életkörülmények (az alapvető szükségletek kielégítése) képezi, míg a felső határ a bioszféra eltartóképessége. ( $A$ ford.)
} 
pénzügyi fókuszú gazdasági müködés felé (amit a COVID-19 fölgyorsította otthoni munka trendje is segíthet) magában is elhozza a kedvezőtlen környezeti hatások csökkenését. Az eddigi tapasztalatok azonban inkább azt mutatják, hogy a szolgáltatási szektorokban dolgozók fogyasztásának növekedése (s az ebböl adódó környezeti kár) túlszárnyalja az átalakuló termelési mintázatok környezeti nyereségét. Mindez újfent azt támasztja alá, hogy a fogyasztás és termelés ökológiailag kedvező megváltoztatására irányuló stratégiáknak kéz a kézben kell járniuk [72]. Számos friss tudományos jelentés alapján összességében kijelenthető, hogy a túlzó fogyasztás csökkentése nélkül nem lehetséges olyan fenntartható jövő, amelyben egyszerre valósul meg az emberi szükségleteink kielégítése és az ökológiai határokon belül maradásunk $[73,74]$.

\section{A természet értékeire nyitott költségvetési politika kialakitása}

A kormányoknak manapság sok fejtörést okoz az, miként hozzák egyensúlyba az állami költségvetést és miként kezeljék a hosszú távon ható pénzügyi megrázkódtatásokat. Ez különösen kényes kérdés azoknál az országos szintnél alacsonyabb szintü államigazgatási szerveknél, amelyek kiegyensúlyozott költségvetés mellett tudnak csak müködni, azaz nem tudnak hitelt felvenni és nem mehetnek csődbe. Ez a helyzet kényszerü döntésekre ösztökél, amelyeknek következményei hosszú távra hatnak ki. Például New York városa, ahol legalább hétmilliárd dollárra rúg a költségvetési hiány az adóbevételek világjárvány kezdete óta tartó csökkenése miatt, több mint $10 \%$-kal tervezi visszavágni a városi parkokra szánt költségvetés teljes összegét - annak ellenére, hogy karantén idején a zöldterületek kiemelkedő szerepet töltenek be a fizikai és mentális egészség megőrzésében [75].

E kihívások fényében fontos lenne, hogy az állami költségvetési politikák továbbra is tükrözzék a természet értékeit. Innovatív finanszírozási megoldásokkal segíthetik kiegyensúlyozni az ország lemaradó térségeinek költségvetését. Például az ökológiai költségvetési transzfereknek hívott közpolitikai eszközök az állami adóbevételeket ökológiai vagy természetvédelmi mutatók (például a védett vagy erdősült területek aránya és természetességi állapota) alapján osztják el a régiók vagy önkormányzatok között. E költségvetési újraelosztási megoldások használhatók arra, hogy kompenzálják a települések természetvédelemre fordított kiadásait vagy ellentételezzék az adott önkormányzat határain túlnyúló környezeti hasznokat [76]. Egyelöre csak néhány ország vezette be az ökológiai költségvetési transzfereket (például Brazília, India, Portugália és Franciaország), holott 
a költségvetési támogatások ilyen irányú átalakítása viszonylag egyszerü, és nem jár magas tranzakciós költséggel [77, 78]. Például India 2015-ben vezette be az ökológiai költségvetési transzfereket, akkor a nemzeti adójövedelem 7,5\%-át osztotta újra erdőborítási indikátorok alapján, de ezt az arányt 2020-ban 10\%-ra emelte [79]. Az ilyen megközelítések ösztönzésével és bővítésével segíteni lehetne a helyi önkormányzatokat természetvédelmi céljaik elérésében, egyúttal több lehetőséget lehetne nyújtani az állampolgárok számára, hogy élvezzék a zöldterületek áldásos hatásait.

\section{A pénzügyi szektor figyelmének ráirányítása}

a természettel kapcsolatos kockázatokra

Szabályozók és ösztönzők keveréke áll a pénzügyi szektor - bankok, államadóssági és nyugdíjalapok, magántőke- és biztosítótársaságok stb. - rendelkezésére, melyekkel bátoríthatják a természetkímélő iparágakba és technológiákba történő befektetéseket [80, 81]. A pénzügyi, biztosítási és ingatlanszektornak egyre több köze van a biodiverzitás csökkenéséhez: így a magántőke számos trópusi országban nagy léptékben sajátít ki területeket - jórészt exportcikkek előállítása számára -, ami még a befektetéssel érintett területeken túl is nagyobb erdőirtással párosul [82], és az ingatlanra specializálódott társaságok befektetései miatt megemelkedő termőföldárak ökoszisztémát átalakító mezőgazdasági terjeszkedést okozhatnak [83]. A biztonságra törekvés trendjei - melyeket az árupiaci indexalapok, a határidős és derivatívapiacok testesítenek meg - drámai mértékben felerősödtek. Ezek az eszközök egyre összetettebbé váltak, a piacokon automatikus algoritmusok kereskednek és a folyamatok többnyire elszakadtak a javak tényleges anyagáramaitól [84, 85]. A határidős (future) ügyletek kulcsszerepet játszanak az olyan mezőgazdasági termények előállításában és kereskedelmében, mint a szója, a kávé és a pálmaolaj. Ám amíg ezek az eszközök a biztos jövedelem és a kockázatkezelés ígéretét hordozzák a termelők számára, addig az árváltozásokkal való spekulációra és fedezeti (hedge) ügyletekre is lehetöséget adnak, amelyek környezeti következményekkel járnak. Jóllehet komoly viták övezik a mezőgazdasági derivatívapiacok szerepét a 2007-2008-as magasabb és szeszélyesebb élelmiszerárakban, egyre több a bizonyíték arra, hogy a spekulációnak szerepe van az egyre gyakrabban előforduló extrém áremelkedésekben, ami befektetéseket vonz a termelés bővítésébe [86].

Így egy, a pénzügyi spekulációra és a természettel összefüggő kockázatokra vonatkozó elővigyázatossági elv érvényesítésére van szükség, tekintettel a katasztrófával fenyegető kilengésekre vagy for- 
dulópontokra (tipping points), amelyek jórészt ismeretlenek és a természetüknél fogva nehéz őket pontosan elöre jelezni [56, 87]. Amint nemrég a járvány és a klímaváltozás kapcsán is megtapasztaltuk, olyan magas a potenciális negatív gazdasági hatása annak, hogy egy kilengés kedvezőtlen oldalára kerüljünk, hogy a túlzott elővigyázatosság a gazdaságilag leginkább hatékony megközelítésnek számít [88]. A 2008-2009-es piaci összeomlás részben a szélsőséges eszközértékekhez való hozzáállás megváltozására vezethető vissza, s emiatt később számos elővigyázatos pénzügyi szabályozást vezettek be [89]. Ehhez hasonlóan az olyan befektetéseket, melyek a környezeti károk révén sokbillió $\left(10^{12}\right)$ dolláros veszteséget okozhatnak, szintén minimum kockázatosnak kellene tekinteni és ennek megfelelően kellene szabályozni őket [80, 90].

A kockázat megértésének és menedzselésének fontosságára tekintettel a pénzügyi szektor fontos nyomásgyakorló lehet abban, hogy mérsékelje a közszféra és a privát szereplők negatív környezeti hatását [37, 91]. A Pénzügyi Rendszer Zöldítésének Hálózata szerint a jegybankok kulcsszerepet játszhatnak környezeti sztenderdek felállításában és betartatásában, karöltve például az Európai Unió új, fenntartható pénzügyi iránymutatásaival. E sztenderdek a bankokat felelőssé teszi befektetéseik társadalmi-környezeti hatásaiért. E folyamat felgyorsítható volna a COVID utáni helyreállítás során [92]. Kutatás is kimutatta, hogy azok a bankok, amelyek környezeti sztenderdeket alkalmaznak, kevésbé kitettek a kockázatoknak [93]. Az olyan „döglött eszközök” kockázatának a hangsúlyozása, mint amilyenek például az olajtartalékok, hatékony stratégia lehet a fosszilisüzemanyag-szektorból való tőkekivonás elősegítésére [94]; s ez a modell alkalmazható volna a biodiverzitással kapcsolatos aggodalmakra is. Így például hangsúlyozni lehetne az agrobiznisz-befektetésekkel járó olyan kockázatokat, mint amilyenek a vegyszerek miatti szennyezésből vagy a kulcsszerepben lévő beporzó rovarok elvesztéséböl származó lehetséges következményekböl fakadnak [95].

Míg az értékpapírok, származtatott ügyletek (derivatívák) és más spekulatív pénzügyi eszközök jelentős ökológiai és gazdasági kockázatot hordoznak, a tőkepiacokon biztonságosabb - és a válság utáni gazdasági felépülésben vonzóbb - lehetőségek is léteznek, például a „zöld” kötvények, amelyek fenntartható beruházásokhoz biztosítanak forrást akár magán, akár állami szereplők számára. A zöld kötvények segítségével milliárdos nagyságrendű forrás gyült össze megújuló energiaforrásokra és alacsony szén-dioxid-kibocsátású infrastruktúrák fejlesztésére [96], ám egyelöre nem érhetők el hasonló lehetőségek a biológiai sokféleséghez kapcsolódóan, különösen mivel a jelenlegi kötvénypiac csupán kevesebb mint 3\%-a irányul mező- 
gazdasági és erdészeti beruházások felé [97]. Egy másik úttörő kezdeményezést testesítenek meg a zöld beruházási bankok, ahol kormányzati garanciákkal, biztosítással vagy a befektetések minimális megtérülésének garantálásával ösztönzik a magántőke beáramlását. Míg a legtöbb zöld beruházási bank az alacsony szén-dioxid-kibocsátású infrastruktúra támogatását célozza meg, e bankok kiterjeszthetnék tevékenységüket a biodiverzitás-barát beruházásokra is (például az ökológiai helyreállítási projektek finanszírozására) [98].

A pénzügyi sztenderdek javítása nem választható el a közérdekü információk átláthatóvá tételétől. A vállalatok társadalmi felelősségvállalásával, a tanúsítványokkal és a különböző minősítéseket jelölő rendszerekkel foglalkozó kutatások azt bizonyítják, hogy a vállalatok fent felsorolt önkéntes akciói bizonyos feltételek teljesülése mellett hatásosak lehetnek [99]. Például az Amazonas-medence és a boreális (szubarktikus) öv őserdőiben zajló tájátalakításokért felelős nagyvállalatokban alapkezelök és intézményi befektetők egy szük köre rendelkezik meghatározó részvényhányaddal, ami kiváló beavatkozási pont lehet [100]. Az aktivista részvényesek és a klímaváltozásra fókuszáló társadalmilag felelős befektetők gyakran használják a Carbon Disclosure Project (CDP) által nyilvánosságra hozott információkat, hogy értékeljék egy adott befektetéshez kapcsolódó kockázatokat és hatásokat [101]. Ehhez hasonlóan müködhetne a biodiverzitásra és az ökoszisztémákra gyakorolt hatások értékelése és nyilvánosságra hozatala is, amely segíthetne jó irányba terelni a befektetéseket és javíthatná a befektetők hírnevét [102]. Ezen önkéntes eszközök azonban sokszor korlátokba ütköznek, többek között azért, mert hiányzik a rendszerszintű monitoring és a beszerzési gyakorlatok hatásainak vizsgálata, mert lényegi tartalom nélkül nem jelentenek többet az üzleti tevékenység zöldre festésénél és leginkább azért, mert a vállalatok számára nem eredményez érdemi gazdasági előnyt, ha fenntarthatóbb gyakorlatokat követnek [103]. A befektetési normák és alapszabályok kibővíthetik a vagyonkezelői felelősséget e problémák némelyikének kezelése érdekében [104]. Például egy harmadik fél beavatkozási joga lehetővé tenné külső szereplők számára, hogy jogi lépéseket tegyenek, ha a szerződésben részt vevő vállalatok által elfogadott alapelvek sérülnek.

\section{A természetvédelem nemzetközi finanszírozásának szinten tartása}

Habár a kormányok pénzügyileg szűkös idők elé néznek az elkövetkező időkben, anyagi támogatásuk rövid és hosszú távon továbbra is nélkülözhetetlen a természetvédelmi és fenntartható fejlödési kezdeményezések globális finanszírozásának fenntartásához. Jelenleg 
a legtöbb ország a GDP-jének csak a töredékét (kevesebb mint 1\%át) költi biodiverzitással kapcsolatos tevékenységekre, akár belföldi támogatások keretében, akár külföldi segélyezés formájában [105], és míg a magánberuházások a múltban jelentős szerepet töltöttek be, mértékük valószínüleg csökkenni fog a jelenlegi gazdasági kihívások következtében [106]. A pandémiát megelőzően sem volt elegendő a természetvédelmi finanszírozás aktuális mértéke: például az Aichi Biodiverzitás Célkitűzések elérését szolgáló beruházások teljes körü végrehajtása - ami a biodiverzitás csökkenésének megfékezését lehetővé tenné - becslések szerint eléri a 440 milliárd USD összköltséget [107]. A biodiverzitásért folytatott globális küzdelem újragondolásának részeként az is felmerült, hogy a természetvédelem finanszírozásához járuljanak hozzá azok a vállalatok, amelyek tevékenysége az ökoszisztémák egészséges müködésétöl függ, mint például az agrár- vagy a halászati szektor szereplői [108].

A szükségletek, ha lehet, most még nagyobbak. A pandémia következtében fellépő munkanélküliség és élelmiszerhiány a fejlődő országokban valószínüleg fokozni fogja a helyi ökoszisztémákra gyakorolt nyomást, amit a mezőgazdasági területek terjeszkedése és a vadon élő fajokkal folytatott kereskedelem gerjeszt, $s$ ami növeli a járványkitörések jövőbeli kockázatát. Friss eredmények máris jelzik, hogy a COVID-19 hatásaként az ökoturizmusból fakadó bevételek visszaesése és a helyi vadörök tevékenységének visszaszorulása igen súlyos következményekkel járt számos természetvédelmi területen [109]. A kis léptékü halászati rendszerek - amelyek egyébként a halászatból élők 90\%-ának adnak munkát - némelyike virtuálisan összeomlott, miután Kína a koronavírus-járvány miatt nem volt hajlandó átvenni a tőlük érkező import árut [110].

Nem meglepő hát, hogy néhány civil szervezet a globális segélycsomagokban prioritást szavazna a természeti erőforrásokra támaszkodó foglalkoztatás és megélhetés védelmének, valamint a védett területek kiterjesztésének [111, 112]. Ugyanakkor a természetvédelemre fordított források növelése magában nem elég a biodiverzitás csökkenésének megállítására, ha a mögöttes hatótényezőket nem kezeljük. A természetvédelem finanszírozását tehát muszáj összehangolni a többi, fent leírt intézkedéssel, amelyek közül némelyik jelentős bevételi forrást biztosíthat a finanszírozási hiányok betömésére [113].

Az egyenlötlenségek figyelembevétele a fenntartható gazdasági kilábalásban

A gazdasági egyenlőtlenségek megléte magában is probléma, de emellett rosszabb környezeti kimenetekhez is vezet; példának okáért a jövedelemegyenlötlenségek mértéktelen fogyasztást és a gazda- 
gabb társadalmi rétegek magasabb szén-dioxid-kibocsátását okozzák [114, 115], de a magasabb egyenlőtlenséggel jellemezhető országokban magasabb a biológiai sokféleség csökkenésének üteme is [116]. Az egyenlötlenségek többféle módon fejtik ki hatásukat: növelik a kockázat mértékét és megváltoztatják a környezeti problémák kezelésére irányuló közösségi ösztönzöket. A környezeti kockázatok terheit például jellemzően az alacsonyabb jövedelmü csoportok viselik; a szegényebb és kisebbségi közösségek gyakran áldozatai a „szennyezés méltánytalanságának”: nem pusztán több környezetszennyezésnek vannak kitéve, de ökológiai lábnyomuk is alacsonyabb, azaz kevesebb szennyezésnek az okozói [117]. Az egyenlőtlenségek továbbá csökkenthetik az emberek motivációját a biológiai sokféleség megőrzését szolgáló kezdeményezésekben való részvételre, ha nem látják annak potenciális előnyét [118], és alááshatják a közjavak megőrzését szolgáló demokratikus döntéshozatalt is [119].

Az egyenlőtlenségek kezelésére szolgáló konvencionális szakpolitikák, úgymint az igazságos adózási rendszerek, a vagyonátruházási illetékek stb., kiegészíthetők a biológiai sokféleséggel kapcsolatos szempontokkal: ilyen lehet például a magas környezeti költséggel jellemezhető luxustermékek általános forgalmi adója [120]. A minimálbérnek szintén lehetnek pozitív környezeti hatásai [121], és a termékek fenntartható életciklus-elemzése is magában foglalhatná például az alkalmazotti létminimum kritériumát [122]. A fenntarthatóbb gazdaság felé mozdulás is eredményezhet egyenlötlenségeket, mint például a munkahelyek megszüntetése bizonyos ágazatokban (így a fosszilis üzemanyagokkal kapcsolatban) [123]. Az igazságos átmenet koncepciója azt az elvet próbálja megragadni, hogy a fenntarthatóbb gazdaságba történő átalakulás költségeit nem szabad, hogy azok viseljék, akikre már most is aránytalanul nagy terhek hárulnak. $A z$ egyenlötlenségek csökkentésére szolgáló gazdasági eszközök, továbbá az energia-, a földhasználat és egyéb szektorok alapvető átállítására ösztöntő beruházások együttes alkalmazása segíthet az igazságosabb átmenet előmozdításában [124].

\section{Új gazdasági mérőszámok és modellek}

Az IPBES Globális Felmérése hangsúlyozta, hogy a jelenlegi hagyományos gazdasági makroökonómiai mérőszámok (például a bruttó hazai termék - GDP) használatának meghaladása szükséges, hogy indikátoraink magukba foglalják a gazdaságra és az életminőségre vonatkozó holisztikusabb és hosszabb távú nézeteket [1]. A konvencionális gazdasági mérőszámok (például a GDP) leváltása azért fontos, mert egyre több a bizonyíték azok korlátozott információtartalmára és hibáira, és e korlátozott információtartalom és hibák követ- 
keztében a konvencionális mutatók használata a gazdasági növekedést és az ehhez kapcsolódó fenntarthatatlan gyakorlatokat mozdítja elő [125]. A konvencionális mérőszámok kiegészítése vagy lecserélése a társadalmi jólét (welfare) alternatív indikátoraival lehetővé tenné az értékek sokféleségének és a jóllét (well-being) különböző dimenzióinak a figyelembevételét [126]. Az olyan mérőszámok, mint a Fenntartható Gazdasági Jólét Mutatója (Index of Sustainable Economic Welfare - ISEW) vagy a Valódi Fejlődés Indikátora (Genuine Progress Indicator - GPI) negatív előjellel veszik figyelembe a „károk” (például a környezetpusztulás, a biológiai sokféleség csökkenése) pénzbeli értékét és pozitívan számolnak olyan ,javakkal” is, amelyek a GDP-ben hagyományosan nem jelennek meg, mint például a mások által meg nem fizetett munkavégzés értéke [127]. Az elmúlt évtizedekben a természeti folyamatokat és ökoszisztémákat más módon figyelembe vevő megközelítéseket is kidolgoztak, ilyen például az anyagáram-elszámolás (Material Flow Accounting) és a természetitőke-elszámolás (Natural Capital Accounting): ezek segítségével nyomon követhető az erőforrások államhatárokon túli áramlása is [128, 129]. A nemzetközi elszámolási rendszerek, mint például az ENSZ Nemzeti Számlák Rendszere, egyre inkább alkalmazzák ezen új mérőszámokat [130], és a helyi, regionális és nemzeti kormányzatok szintén érdeklődést mutatnak ezek iránt [131]. Bár ezen új környezeti számviteli megközelítések hatásosságával kapcsolatban egyelöre nincs elég empirikus bizonyíték, mindenképpen hasznos eszközök lehetnek a természet sokféle értékével kapcsolatos párbeszéd elősegítésében.

\section{Következtetések}

\section{A fenntartható gazdaság víziója}

Korábban úgy tekintettek a trendtörő változásra, mint ami a drámai fenntarthatósági átmenet egyik legfőbb ösztönzője [132]. Most soha vissza nem térő lehetőségünk van arra, hogy megragadjuk a pillanatot és fontolóra vegyük, milyen gazdasági rendszerre van szükségünk a pandémia után egy fenntartható, igazságos és méltányos jövőhöz [133]. Mindig is úgy tünt, hogy a status quóval való bíbelődés nem elégséges a biodiverzitás-válság nagyszabású kihívásának kezeléséhez, ezért helyénvaló a jelenlegi COVID-19 krízist kihasználni arra, hogy irányt váltsunk és újragondoljuk a természetvédelem és a globális gazdaság müködését $[134,135]$. Társadalmainknak dönteniük kell, hogy megpróbálnak-e visszatérni az eddigi fejlődési pályára vagy kialakítanak egy újat. Legtöbbünk új tapasztalatokkal gazdagodott arról, mi az, ami valóban „elengedhetetlen” egy járvány idején, s 
ez bizonyosan hatással van arra is, hogy 2020 eleje óta mit gondolunk a fenntarthatóságról - ha beleértjük azt, hogy a rendelkezésünkre áll mindaz, ami a méltó és jó élethez szükséges a planetáris határokon belül maradva.

A társadalmi fordulópontokat (vagy másként átbillenési pontokat) úgy határozzák meg, mint fokozatosan megjelenő küszöbértékeket, amelyeknél a kis lépésekben zajló társadalmi-gazdasági változások hirtelen nem lineáris kimeneteket eredményeznek, gyakran pozitív visszacsatolások vagy kaszkád mechanizmusok révén [136]. Bár vannak nézeteltérések abban, hogy ezek az átbillenési pontok miként jelennek meg, a nyomukban kialakuló „ragályos folyamatokra” példaként a technológiai fejlesztések villámgyors terjedését, a társadalmi normák és viselkedések átalakulását vagy a nehezen előre jelezhető, elszabaduló gazdasági átalakulásokat szokták felhozni [137, 138]. Külső sokkhatások előidézhetnek ilyen fordulópontokat (bár nem mindig történik így), és számos példát ismerünk olyan pozitív és negatív politikai változásokra, amelyek hasonló krízisek nyomán indultak el. Ilyen például a Tiszta Víz Törvény (Clean Water Act), amit az Egyesült Államokban vezettek be, miután publicitást kaptak a folyókat ért szennyeződések, vagy az atomerőművek leszerelése Németországban a 2011-es fukushimai atombalesetet követően [139, 140]. Ami közös ezekben a figyelemfelhívó eseményekben, az az, hogy nem rutinszerüek, azaz a kialakult érdekcsoportokat szétzilálják és új koalíciókat hoznak létre, villámgyors tanulást eredményeznek politikai szinten, és utólag felértékelik a válságkezelést [141]. Ebből arra következtethetünk, hogy ahhoz, hogy a normákban és a cselekvések hátterében történt elmozdulások sikeresen áthassák a közpolitika napirendjét és elterjesszék a fenntarthatóságra törekvő politikákat, új érdekcsoportok bevonására, továbbá az ötletek társadalmi hálózatokon keresztüli terjedésére és a több szinten összehangolt cselekvés értékének felismerésére van szükség [142, 143]. A transzformatív változást kereső vállalatok ezzel egy időben olyan stratégiát követnek, amelynek része az új gyakorlatokról létrejött tudás megosztása, a vállalati vezetés (corporate leadership), valamint a politikai koalícióépítés (4. ábra) [144].

A poszt-COVID világ újraalkotásához vezető útvonalak azonban mindeddig igen korlátosak. Bár extrém gyors politikai cselekvést láttunk a karanténintézkedések meghozatala során és hatalmas összegeket mozgósítottak a gazdasági szereplők megsegítése érdekében, aggasztó, hogy nem látunk érdemi előrelépést a gazdaságélénkítő csomagok és az alapvető reformok összekapcsolásában, sőt, egyes gazdaság-helyreállító intézkedések pont az ellenkező irányba visznek. Az adók mérséklése, a fosszilis energiahordozók kitermelésének 
támogatása vagy a környezetvédelmi elöírások lazítása mind „helyreállító" intézkedések, amelyeket Kanadától Vietnámig sok ország alkalmaz (2. ábra és Függelék, 2. táblázat). Még az ambiciózusabb politikai javaslatok is, mint az Egyesült Államok Green New Dealje, amely az alacsony szén-dioxid-kibocsátású infrastruktúrát és az ökológiai restaurációt állítja a beruházások középpontjába, elsősorban a Keynes-i közgazdaságtan kibővített víziója alapján próbálja megoldani a gazdasági problémákat [145]. Ez a megközelítés nem képes megfelelően kezelni a biodiverzitás- és klímaválság mögött meghúzódó gazdasági mozgatórugók megreformálásának mélyreható kérdéseit (amelyeket e cikkben bemutattunk), például a nemzetközi kereskedelem által előidézett, földrészeken átívelő környezeti-társadalmigazdasági kölcsönhatásokat, vagy a termelési rendszerek pénzügyi kitettségének növekedését.

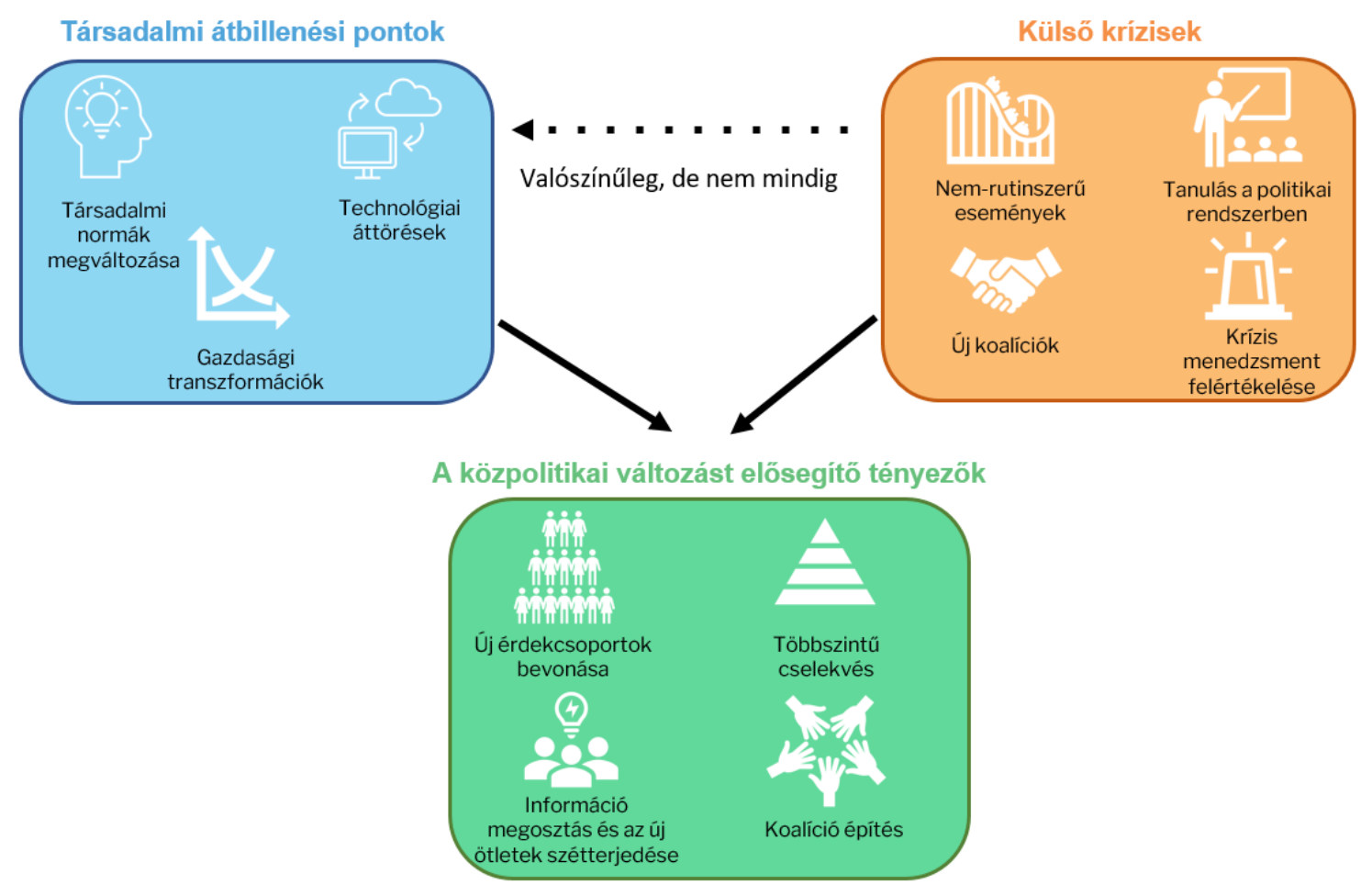

4. ábra A krízisek és a társadalmi fordulópontok lehetőséget nyitnak a közpolitika átalakulására (A társadalmi fordulópontok /amikor a fokozatos, kis léptékü változások hirtelen átalakulnak és felgyorsult ütemben, nem lineáris irányba haladnak tovább/ és a külső krízisek /például katasztrófák/ új utakat nyitnak a közpolitikai vízióalkotás és a változás iránti elköteleződés elött. A közpolitikai átalakulásokat vizsgáló empirikus példák azt mutatják, hogy az új politikai napirend kialakitása és az innovatív politikák elterjedése számos különböző, az állami és a magánszektorban zajló mechanizmus segítségével mehet végbe.) 
A természet integrálása a gazdasági és az állami szektorba merész elképzeléseket fog igényelni, amelyeket, úgy tűnik, kevés ország hajlandó vállalni, még annak ellenére is, hogy befolyásos szervezetek számos ütemtervet javasoltak az „építsük újra jobban” jegyében [146, 147]. Nem valószínü, hogy elszigetelt beavatkozások - különösen azok, amelyek a biodiverzitást, a klímaváltozást és a COVID-19 járványt különálló problémaként kezelik - transzformatív változást tudnak előidézni, holott kutatások igazolták, hogy az Egyesült Államokban a közvélemény támogatja a klíma-, a szociális és a gazdaságpolitika ötvözését [148]. Egy „eszköztár” jellegü megközelítés (amit itt bemutattunk), amelyben opciók széles skáláját értékelik és alkalmazzák a szakpolitikai beavatkozások egyvelegében, valószínüleg hatékonyabb, mint egy „tökéletes megoldás” kizárólagos használata, továbbá egyértelmü kapcsolatra van szükség a rövid távú helyreállító beavatkozások és a hosszabb távú befektetések között [27]. Ez részben azért van így, mert a jelenleg előttünk álló problémák komplexek, számos mögöttes mozgatórugó áll a hátterükben és ezért megoldásukhoz többféle eszközre és hosszú távú nézőpontra van szükség. Másrészt azonban a politikai szükségletek is indokolják, hogy többféle opció közül lehessen választani, amelyek a különböző érintettek számára eltérően vonzóak, s így a szereplők megtalálhatják a számukra alkalmasat $[33,56]$.

Továbbra is kulcsfontosságú kérdés, hogyan lehet ambícióik növelésére ösztönözni a politikai döntéshozókat és az üzleti élet vezetőit, ugyanakkor jelentős környezeti tanulmányok (köztük az IPBES Globális Felmérése, valamint az a kutatás, amely igazolta, hogy a húsz Aichi Célkitüzés közül egyet sem sikerült időben teljesíteni) felhívták a figyelmet arra, hogy a fenntarthatóság felé tett előrelépés egyelöre elmaradt és rávilágítottak jelenlegi megközelítéseink korlátjaira és a változások lassúságára [149]. A COVID-válság révén olyan új lehetőségek nyílhattak, amelyek még hat hónappal ezelőtt sem voltak elérhetőek - a kormányzat és a magánszektor elköteleződésével kapcsolatos társadalmi elvárások minden szinten fokozódtak. Öszszességében, egy új gazdasági paradigma kigondolása és megvalósítása - amely megoldja mindazt a sok kihívást, amellyel ma szembesülünk - jelentős feladat lesz. Mindez transzformatív jövőképet igényel és ki kell használnia az előttünk álló rendkívüli válsághelyzetben rejlö lehetőséget. Egy ilyen megközelítés úgy fogja átalakítani a globális gazdaságot irányító ösztönzőket és politikákat, hogy azok megőrizzék, ne pedig aláássák a biológiai sokféleséget, világunkat pedig az ökológiai és társadalmi fenntarthatóság felé tereljék. 


\section{Függelék}

Az internetes függelék (Supplementary Material) az alábbi linken keresztül érhető el (angol nyelven):

https://doi.org/10.1016/j.oneear.2020.09.011

\section{HIVATKOZÁSOK}

1. Intergovernmental Science-Policy Platform on Biodiversity and Ecosystem Services (IPBES). (2019) Summary for Policymakers of the Global Assessment on Biodiversity and Ecosystem Services (IPBES) https://ipbes.net/news/ipbes-global-assessment-summarypolicymakers-pdf

2. Díaz, S., Settele, J., Brondizio, E., Ngo, H., Agard, J., Arneth, A., Balvanera, P., Brauman, K., Butchart, S., Chan, K. et al. (2019). Pervasive human-driven decline of life on Earth points to the need for transformative change. Science 366, 6471 https://doi.org/10.1126/science.aax3100

3. Liu, J., Hull, V., Luo, J., Yang, W., Liu, W., Viña, A., Vogt, C., Xu, Z., Yang, H., Zhang, J. et al. (2015). Multiple telecouplings and their complex interrelationships. Ecol Soc 20 (3)

http://www.jstor.org/stable/26270254

4. Dobson, A. P., Pimm, S., Hannah, L., Kaufman, L., Ahumada, J., Ando, A., Bernstein, A., Busch, J., Daszak, P., Engelmann, J. et al. (2020). Ecology and economics for pandemic prevention. Science 369 (6502), 379-381.

5. World Economic Forum (2020). Global Risks Report (WEF) https://reports.weforum.org/global-risks-report-2020/

6. IPSOS (2020). Two thirds of citizens around the world agree climate change is as serious a crisis as Coronavirus (IPSOS). https://www.ipsos.com/en/two-thirds-citizens-around-world-agreeclimate-change-serious-crisis-coronavirus

7. Hepburn, C., O'Callaghan, B., Stern, N., Stiglitz, J., and Zenghelis, D. (2020). Will COVID-19 fiscal recovery packages accelerate or retard progress on climate change? Oxf Rev Econ 36 (S1), graa015 https://doi.org/10.1093/oxrep/graa015

8. Lambertini, M., Maruma Mrema, E., and Neira, M. (2020). Coronavirus is a warning to us to mend our broken relationship with

\footnotetext{
*A hivatkozások jegyzékét az eredeti cikk formátumában közöljük. (A szerk.)
} 
nature. The Guardian, June 17

https://www.theguardian.com/commentisfree/2020/jun/17/coronaviru s-warning-broken-relationship-nature

9. Eskew, E. and Carlson, C. (2020). Overselling wildlife trade bans will not bolster conservation or pandemic preparedness. Lancet Planet. Health 4, e215-e216.

10. Vivid Economics (2020). Green Stimulus Index: An Assessment of the Orientation of COVID-19 Stimulus in Relation to Climate Change, Biodiversity and Other Environmental Impacts (Finance for Biodiversity Initiative). https://www. vivideconomics.com/wpcontent/uploads/2020/08/200820-GreenStimulusIndex_web.pdf

11. OECD (2019). Biodiversity: Finance and the Economic and Business Case for Action (Organization for Economic Cooperation and Development)

https://www.oecd.org/environment/resources/biodiversity/G7-reportBiodiversity-Finance-and-the-Economic-and-Business-Case-forAction.pdf

12. Franks, M., Lessmann, K., Jakob, M., Steckel, J., and Edenhofer, O. (2018). Mobilizing domestic resources for the Agenda 2030 via carbonpricing. Nature Sustainability 1, 350-357.

13. Coady, D., Parry, I., Le, N. P., and Shang, B. (2019). Global Fossil FuelSubsidies Remain Large: An Update Based on CountryLevel Estimates. IMF Working Papers 19, 39.

14. Sumaila, U., Ebrahim, N., Schuhbauer, A., Skerritt, D., Li, Y., Kim, H.S., Mallory, T., Lam, V., and Pauly, D. (2019). Updated estimates and analysis of global fisheries subsidies. Mar Policy, 103695 https://doi.org/10.1016/j.marpol.2019.103695

15. Dempsey, J., Martin, T., and Sumaila, U. (2020). Subsidizing extinction? Conserv Lett 13, e12705.

16. OECD (2017). The Political Economy of Biodiversity Policy Reform (Organization for Economic Cooperation and Development). https://doi.org/10.1787/9789264269545-en

17. Scown, M., Brady, M. and Nicolas, K. (2020). Billions in misspent EU agricultural subsidies could support the Sustainable Development Goals. One Earth 3, 237-250.

18. Morefield, P., Le Duc, S., Clark, C., and lovanna, R. (2016).

Grasslands, wetlands, and agriculture: the fate of land expiring from the Conservation Reserve Program in the Midwestern United States. 
Environ. Res. Lett. 11, 094005 https://doi.org/10.1088/17489326/11/9/094005

19. Pe'er, G., Zinngrebe, Y., Moreira, F., Sirami, S., Schindler, S., Müller, R., Bontzorlos, V., Clough, D., Bezák, P. Bonn, A. et al. (2019). A greener path for the EU Common Agricultural Policy. Science 365, 449-451.

20. Simoncini, R., Ring, I., Sandström, C., Albert, C., Kasymov, U., and Arlettaz, R. (2019). Constraints and opportunities for mainstreaming biodiversity and ecosystem services in the EU's Common Agricultural Policy: Insights from the IPBES assessment for Europe and Central Asia. Land Use Policy 88, 104099.

21. Reisch, L., Eberle, U., and Lorek, S. (2013). Sustainable food consumption: An overview of contemporary issues and policies. Sustainability: Science, Practice, and Policy 9, 7-25. https://doi.org/10.1080/15487733.2013.11908111

22. Lindström, H., Lundberg, S., and Marklund, P. O. (2020). How green public procurement can drive conversion of farmland: An empirical analysis of an organic food policy. Ecol. Econ. 172, 106622.

23. IPCC (2019). Special Report on Climate Change and Land (IPCC)

https://www.ipcc.ch/site/assets/uploads/sites/4/2020/02/SPM_Updat ed-Jan20.pdf

24. Henry, R., Alexander, P., Rabin, S., Anthoni, P., Rounsevell, M. and Arneth, A. (2019) The role of global dietary transitions for safeguarding biodiversity. Global Environ Change 58, 101956, https://doi.org/10.1016/j.gloenvcha.2019.101956

25. Vanbergen, A., Aizen, M., Cordeau, S., Garibaldi, L., Garratt, M., Kovács-Hostyánszki, A. Lecuyer, L., Ngo, H. Potts, S., Settele, J. et al. (2020). Transformation of agricultural landscapes in the Anthropocene: Nature's contributions to people, agriculture and food security. Adv Ecol Res, forthcoming

26. Ekins, P. (1999). European environmental taxes and charges:

Recent experience, issues and trends. Ecol Econ 31, 39-62. https://doi.org/10.1016/S0921-8009(99)00051-8

27. Barbier, E. (2020). Greening the post-pandemic recovery in the G20. Environ. Res. Econ. 76, 685-703.

28. Hogg, D., Skou Andersen, M., Elliott, T., Sherrington, C., Vergunst, T., Ettlinger, S., Elliott, L., and Hudson, J. (2014). Study 
on Environmental Fiscal Reform Potential in 12 EU Member States (European Commission). https://doi.org/10.2779/792305

29. Boyce, J. K. and Pastor, M. (2013). Clearing the air: incorporating air quality and environmental justice into climate policy. Clim. Change 120, 801-814. https://doi.org/10.1007/s10584013-0832-2

\section{Boyce, J. K. (2019). The Case for Carbon Dividends (Polity Press)}

31. Barbier, E., Lozano, R., Rodríguez, C. M. and Troëng, S. (2020). Adopt acarbon tax to protect tropical forests. Nature 578, 213-216.

32. Hilton, D., Charalambides, L., Demarque, C., Waroquier, L., \& Raux, C. (2014). A tax can nudge: The impact of an environmentally motivated bonus/malus fiscal system on transport preferences. $J$ Econ Psychol 42, 17-27.

33. Sterner, T., Barbier, E. B., Bateman, I., van den Bijgaart, I., Crépin, A. S., Edenhofer, O., et al. (2019). Policy design for the Anthropocene. Nat Sustain 2 (1), 14-21.

34. Rosenbloom, D. and Markard, J. (2020). A COVID-19 recovery for climate. Science 368 (6490), 447.

35. Galaz, V., Crona, B., Dauriach, A., Jouffray, J. B., Österblom, H. and Fichtner, J. (2018). Tax havens and global environmental degradation. Nat. Ecol. Evol. 2, 1352-1357.

36. Richards, M. J. (2016). Regulating automakers for climate change: US reforms in global context. Env. Pol. Gov. 26, 498-509. https://doi.org/10.1002/eet.1726

37. UNEP (2020). Beyond 'Business as Usual': Biodiversity Targets and Finance (UNEP) https://www.unepfi.org/wordpress/wpcontent/uploads/2020/06/Beyond-Business-As-Usual-Full-Report.pdf 38. Carić, H \& Mackelworth, P. (2014). Cruise tourism environmental impacts - The perspective from the Adriatic Sea. Ocean Coast. Manage 102, 350-363. https://doi.org/10.1016/j.ocecoaman.2014.09.008

39. Jotzo, F., Longden, T. and Anjum, Z. (2020). Fiscal Stimulus for Low-carbon Compatible COVID-19 recovery: Criteria for Infrastructure Investment. (Centre for Climate \& Energy Policy, Crawford School of Public Policy, Australian National University) 40. Norton, A., Seddon, N., Agrawal, A., Shakya, C., Kaur, N., and Porras, I. (2020). Harnessing employment-based social assistance 
programmes to scale up nature-based climate action. Phil. Trans. R. Soc. B 375, 20190127. https://doi.org/10.1098/rstb.2019.0127

41. Mell, I. (2016). Global Green Infrastructure: Lessons for Successful Policy-making, Investment and Management (Routledge)

42. Edwards, P., Sutton-Grier, A. and G. Coyle (2013). Investing in nature: Restoring coastal habitat blue infrastructure and green job creation. Mar. Policy 38, 65-71.

https://doi.org/10.1016/j.marpol.2012.05.020

43. Ernst and Young (2020). Delivering Economic Stimulus through the Conservation and Land Management Sector. (Pew Charitable Trusts, The Nature Conservancy, NRM Regions Australia, Australian Conservation Foundation, Australian Land Conservation Alliance, NRM Regions Queensland, Conservation Council of South Australia)

44. Turpie, J. K., Marais, C., and Blignaut, J. N. (2008). The working for water programme: Evolution of payments for ecosystem services mechanisms that address both poverty and ecosystem service delivery in South Africa. Ecol Econ 65, 788-798.

45. Molina, G. and Ortiz-Juarex, E. (2020). Temporary Basic Income: Protecting Poor and Vulnerable People in Developing Countries (United Nations Development Program Transition Series Working Papers)

46. Banerjee, A., Niehaus, P., and Suri, T. (2019). Universal basic income in the developing world. Annu Rev Econ 11, 959-983.

47. Hoynes, H., and Rothstein, J. (2019). Universal basic income in the United States and advanced countries. Annu Rev Econ 11, 929958.

48. Van Parijs, P. and Vanderborght, Y. (2017). Basic Income (Harvard University Press)

49. MacNeill, T., \& Vibert, A. (2019). Universal basic income and the natural environment: Theory and policy. Basic Income Studies 14 (1) https://doi.org/10.1515/bis-2018-0026

50. Howard, M., Pinto, J., and Schachtschneider, U. (2019).

Ecological effects of basic income. In The Palgrave International Handbook of Basic Income, M. Torry, ed. (Palgrave Macmillan), 111-132.

51. Fletcher, R. and Buscher, B. (2020). Conservation basic income: A non-market mechanism to support convivial conservation. Biol Cons 244, 108520 
52. Ferraro, P. \& Simorangkir, R. (2020). Conditional cash transfers to alleviate poverty also reduced deforestation in Indonesia. Sci Adv 12 Jun, EAAZ1298 https://doi.org/10.1126/sciadv.aaz1298

53. Wilebore, B., Voors, M., Bulte, E.H., Coomes, D. and Kontoleon, A. (2019). Unconditional Transfers and Tropical Forest

Conservation: Evidence from a Randomized Control Trial in Sierra Leone. Am J Agr Econ 101, 894-918.

https://doi.org/10.1093/ajae/aay105

54. Salzman, J., Bennett, G., Carroll, N., Goldstein, A. \& Jenkins, M. (2018). The global status and trends of Payments for Ecosystem Services. Nat Sustain 1, 1-9.

55. Sarkis, J., Cohen, M. J., Dewick, P. and Schröder, P. (2020). A brave new world: Lessons from the COVID-19 pandemic for transitioning to sustainable supply and production. Resour Conserv Recycl 159, 104894.

https://doi.org/10.1016/j.resconrec.2020.104894

56. Nyström, M., Jouffray, J. B., Nordstrom, A., Crona, B., Søgaard Jørgensen, P., Carpenter, S., Bodin, Ö., Galaz, V. and Folke, C. (2019). Anatomy and resilience of the global production ecosystem. Nature 575, 98-108.

57. Clapp, J. (2014). Financialization, distance and global food politics. J Peasant Stud 41, 797-814.

58. Douwe van der Ploeg, J. (2020). From biomedical to politicoeconomic crisis: the food system in times of Covid-19. J Peasant Stud 47, 944-972, https://doi.org/10.1080/03066150.2020.1794843

59. Loker, A. and Francis, C. (2020). Urban food sovereignty: urgent need for agroecology and systems thinking in a post-COVID-19 future. Agroecol Sust Food 44, 1118-1123. https://doi.org/10.1080/21683565.2020.1775752

60. Malak-Rawlikowska, A., Majewski, Was, A., Borgen, S., Csillag, P., Donati, M., Freeman, R., Hoàng, V., Lecoeur, J. L, Mancini, M., Nguyen, A. et al. (2019). Measuring the economic, environmental, and social sustainability of short food supply chains. Sustainability 11, 4004 https://doi.org/10.3390/su11154004

61. Deppermann, A., Havlík, P., Valin, H. Boere, E., Herrero, M., Vervoort, J., and Mathijs, E. (2018). The market impacts of shortening feed supply chains in Europe. Food Secur 10, 14011410. https://doi.org/10.1007/s12571-018-0868-2 
62. Sellitto, M., Machado Vial, L. and Viegas, C. (2018). Critical success factors in short food supply chains: Case studies with milk and dairy producers from Italy and Brazil. J Clean Prod 170, 13611368. https://doi.org/10.1016/j.jclepro.2017.09.235

63. Kinnunen, P., Guillaume, J. H. A., Taka, M., D'Odorico, P., Siebert, S., Puma., M., Jalava, M., and Kummu, M. (2020). Local food crop production can fulfil demand for less than one-third of the population. Nat Food 1, 229-237. https://doi.org/10.1038/s43016020-0060-7

64. Birbeck, C. D. (2019). WTO reform: A forward-looking agenda on environmental sustainability. In WTO Reform: Reshaping Global Trade Governance for 21st Century Challenges, T. Soobramanien, B. Vickers, and H. Enos-Edu, eds. (Commonwealth Secretariat), 33-59.

65. Rocchi, P., Serrano, M., Roca, J., and Arto, I. (2018). Border carbon adjustments based on avoided emissions: Addressing the challenge of its design. Ecol Econ 145, 126-136.

66. Folke, C., Österblom, H., Jouffray, J-B., Lambin, E. F., Adger, W. N., Scheffer, M., Crona, B. I., Nyström, M., Levin, S. A., Carpenter, S. R. et al. (2019). Transnational corporations and the challenge of biosphere stewardship. Nat Ecol Evol 3, 1396-1403.

67. Goffman, E. (2020). In the wake of COVID-19, is glocalization our sustainability future? Sustainability: Science, Practice and Policy 16, 48-52. https://doi.org/10.1080/15487733.2020.1765678

68. Bengtsson, M., Alfredsson, E., Cohen, M., Lorek, S., and Schroeder, P. (2018). Transforming systems of consumption and production for achieving the sustainable development goals: moving beyond efficiency. Sustain Sci 13, 1533-1547.

69. Gough, I. (2017). Recomposing consumption: defining necessities for sustainable and equitable well-being. Philos T R Soc A. 375,20160379

70. Wiedmann, T., Lenzen, M., Keyßer, L. T. and Steinberger, J. (2020). Scientists' warning on affluence. Nat Commun 11, 3107. https://doi.org/10.1038/s41467-020-16941-y

71. Parrique T., Barth J., Briens F., C. Kerschner, Kraus-Polk A., Kuokkanen A. and Spangenberg, J. H. (2019). Decoupling Debunked: Evidence and Arguments against Green Growth as a Sole Strategy for Sustainability (European Environmental Bureau) 
72. Horen Greenford, D., Crownshaw, T., Lesk, C., Stadler, K., and Matthews, H. D. (2020). Shifting economic activity to services has limited potential to reduce global environmental impacts due to the household consumption of labour. Environ. Res. Lett. 15, 064019

73. Roxburgh, T., Ellis, K., Johnson, J. A., Baldos, U. L., Hertel, T., Nootenboom, C., and Polasky, S. (2020). Global Futures: Assessing the Global Economic Impacts of Environmental Change to Support Policy-making. (World Wildlife Fund) https://www.wwf.org.uk/globalfutures

74. O'Neill, D. W., Fanning, A. L., Lamb, W. F., and Steinberger, J. (2018). A good life for all within planetary boundaries. Nat. Sustain 1, 88-95.

75. Walker, E. (2020). Testimony before New York City Council Committee on Finance Executive Budget Hearing (New Yorkers for Parks) http://www.ny4p.org/client-uploads/pdf/Testimony/NY4PExecutive-Budget-Testimony-May-21-2020.pdf

76. Ring, I., Droste, N., and Santos, R. (2017). Ecological fiscal transfers (EFT). In: Opportunities for Innovative Biodiversity Financing in the EU, M. Kettunen and A. Illes, eds. (Institute for European Policy), 8-43.

http://ec.europa.eu/environment/nature/natura2000/financing/docs/K ettunen_2017_financing_biodiversity_case_studies.pdf

77. Droste, N., Lima, G. R., May, P. H., and Ring, I. (2017).

Municipal responses to Ecological Fiscal Transfers in Brazil - a microeconometric panel data approach. Environ Pol Gov 27, 378393.

78. Santos, R., Ring, I., Antunes, P., and Clemente, P. (2012).

Fiscal transfers for biodiversity conservation: the Portuguese Local Finances Law. Land Use Policy 29, 261-273.

79. Busch, J., Kapur, A., Mukherjee, A. (2020). Did India's ecological fiscal transfers incentivize state governments to increase their forestry budgets? Environ Res Commun 2, 031006.

https://doi.org/10.1088/2515-7620/ab817c

80. UNEP (2015). The Financial System We Need: Aligning the Financial System with Sustainable Development (United Nations Environment Program)

81. Galaz, V., Gars, J., Moberg, F., Nykvist B. and Repinski, C. (2015). Why ecologists should care about financial markets. Trends Ecol. Evol. 30, 571-580. 
82. Davis, K. F., Koo, H. I., Dell'Angelo, J., DiOrorico, P., Estes, L., Kehoe, L., Kharratzadeh, M., Kuemmerle, T., Machava, D., and Rodrigues Pais, A. et al. (2020). Tropical forest loss enhanced by large-scale land acquisitions. Nat Geosci 13, 482-488. https://doi.org/10.1038/s41561-020-0592-3

83. Clapp, J. and Isakson, S. R. (2018). Risky returns: The implications of financialization in the food system. Dev. Change 49, 437-460.

84. Clapp, J. and Helliner, E. (2012). Troubled futures? The global food crisis and the politics of agricultural derivatives regulation. Rev Int Polit Econ 19, 181-207.

85. Galaz, V. and Pierre, J. (2017). Superconnected, complex and ultrafast: governance of hyperfunctionality in financial markets.

Complexity, Governance \& Networks 3, 12-28.

86. Tadesse, G. et al. (2014). Drivers and triggers of international food price spikes and volatility. Food Policy 47, 117-128.

https://doi.org/10.1016/j.foodpol.2013.08.014

87. Hillebrand, H., Donohue, I., Harpole, W., Hodapp, D., Kucera, M., Lewandowska, A., Merder, J., Montoya, J., and Freund, J.

(2020). Thresholds for ecological responses to global change do not emerge from empirical data. Nat Ecol Evol

https://doi.org/10.1038/s41559-020-1256-9

88. Weitzman, M. (2011). Fat-tailed uncertainty in the economics of catastrophic climate change. Rev Environ Econ Policy 5, 275-292. https://doi.org/10.1093/reep/rer006

89. Young, K. and Park, S. (2013). Regulatory opportunism: Crossnational patterns in national banking regulatory responses following the global financial crisis. Public Admin 91, 561-581. https://doi.org/10.1111/j.1467-9299.2012.02102.x

90. Kedward, K., Ryan-Collins, J. and Chenet, H. (2020). Managing Nature-related Financial Risks: A Precautionary Policy Approach for Central Banks and Financial Supervisors. (UCL Institute for Innovation and Public Purpose, Working Paper Series) https://www.ucl.ac.uk/bartlett/public-purpose/wp2020-09

91. Jouffray, J., Crona, B., Wassénius, E., Bebbington, J., and Scholtens, B. (2019). Leverage points in the financial sector for seafood sustainability. Sci Adv 5, eaax3324 https://doi.org/10.1126/sciadv.aax3324 
92. EU High-Level Expert Group on Sustainable Finance (2019). Financing a Sustainable European Economy: Final Report of the High-Level Expert Group on Sustainable Finance (European Union). https://ec.europa.eu/info/sites/info/files/180131-sustainable-financefinal-report_en.pdf

93. Gangi, F., Meles, A., D'Angelo, E. and Daniele, L. M. (2018). Sustainable development and corporate governance in the financial system: Are environmentally friendly banks less risky? Corp Soc Resp Env Ma. 26, 529-547.

94. Caldecott, B. (2017). Introduction to special issue: stranded assets and the environment. J Sustainable Finance \& Investment 7, $1-13$.

95. WWF France (2019). Into the Wild: Integrating Nature into Investment Strategies. (World Wildlife Fund) https://d2ouvy59p0dg6k.cloudfront.net/downloads/report_wwf_franc e__axa_into_the_wild_may_2019_dv.pdf

96. Flammer, C. (2020). Green bonds: Effectiveness and implications for public policy. Environ Energy Policy Econ 1, 95-128.

97. Climate Bonds Initiative (2020). Unlocking Brazil's Green Investment Potential for Agriculture (CBI) https://www.climatebonds.net/files/reports/brazil_agri_roadmap_engl ish.pdf

98. OECD (2016). Green Investment Banks: Scaling up Private Investment in Low-carbon, Climate-resilientInfrastructure, Green Finance and Investment (OECD Publishing). https://doi.org/10.1787/9789264245129-en

99. Boiral, O., Heras-Saizarbitoria, I. and Brotherton, M. C. (2017). Corporate biodiversity management through certifiable standards. Bus Strategy Environ 27, 389-402.

100. Galaz, V., Crona, B., Dauriach, A., Scholtens, B. and Steffen, W. (2018). Finance and the Earth system - Exploring the links between financial actors and non-linear changes in the climate system. Global Environ Chang 53, 296-302.

https://doi.org/10.1016/j.gloenvcha.2018.09.008

101. Qian, W. and Schaltegger, S. (2017). Revisiting carbon disclosure and performance: Legitimacy and management views. $\mathrm{Br}$ Account Rev 49, 365-379.

102. Skouloudis, A., Malesios, C., and Dimitrakopoulos, P. (2019). Corporate biodiversity accounting and reporting in mega-diverse 
countries: An examination of indicators disclosed in sustainability reports. Ecol Indic 98, 888-901.

103. Lambin, E. F., Gibbs, H., Heilmayr, R., Carlson, K., Fleck, L., Garrett, R., le Polain de Waroux, Y., McDermott, C., McLaughlin, D., Newton, P., Nolte, C. et al. (2018). The role of supply-chain initiatives in reducing deforestation. Nat Clim Change 8, 1-8.

104. Gary, S. (2019). Best interests in the long term: Fiduciary duties and ESG integration. U. Colo. L. Rev. 90, 371.

105. Waldron, A., Miller, D. C., Redding, D., Mooers, A., Kuhn, T. S., Nibbelink, N. J., Roberts, T., Tobias, J. A., Gittleman, J. (2017). Reductions in global biodiversity loss predicted from conservation spending. Nature 7680, 364-367.

106. Zavaleta, E., Miller, D. C., Salafsky, N., Fleishman, E., Webster, M., Gold, B., Hulse, D., Rowen, M., Tabor, G. and Vanderryn, J. (2008). Enhancing the engagement of US private foundations with conservation science. Cons Biol 22, 1477-1484.

107. Convention on Biological Diversity (2014). Resourcing the Aichi Biodiversity Targets: An Assessment of Benefits, Investments and Resource needs for Implementing the Strategic Plan for Biodiversity 2011-2020. (High-Level Panel on Global Assessment of Resources for Implementing the Strategic Plan for Biodiversity 2011-2020) 108. Barbier, E. Burgess, J., and Dean, T. (2018). How to pay for saving biodiversity. Science 360, 486-488.

109. Lindsey, P., Allan, J., Brehony, P., Dickman, A., Robson, A., Begg, C., Bhammar, H., Blanken, L., Breuer, T., Fitzgerald, K. et al. (2020). Conserving Africa's wildlife and wildlands through the COVID-19 crisis and beyond. Nat Ecol Evol, https://doi.org/10.1038/s41559-020-1275-6

110. Knight, C., Burnham, T., Mansfield, E., Crowder, L., and Micheli, F. (2020). COVID-19 reveals vulnerability of small-scale fisheries to global market systems. Lancet Planetary Health 4, e219 https://doi.org/10.1016/S2542-5196(20)30128-5

111. Campaign for Nature (2020). A Key Sector Forgotten in the Stimulus Debate: The Nature-Based Economy (Campaign for Nature and National Geographic Society) https://static1.squarespace.com/static/5c77fa240b77bd5a7ff401e5/t/ 5ee7f56d2b688176ffb9ebf9/1592259976939/White+PaperFinal_sml .pdf 
112. Waldron, A., Adams, V., Allan, J., Arnell, A., Asner, G., Atkinson, S., Baccini, A., Baillie, J., Balmford, A., Beau, A., et al. (2020). Protecting 30\% ofthe Planet for Nature: Costs, Benefits and Economic Implications (Campaign for Nature). https://www.conservation.cam.ac.uk/files/waldron_report_30_by_30 _publish.pdf

113. Deutz, A., Heal, G. M., Niu, R., Swanson, E., Townshend, T., Zhu, L., Del-mar, A., Meghji, A., Sethi, S. A. and Tobin-de la Puente, J. (2020). Financing Nature: Closing the Global Biodiversity Financing Gap (ThePaulson Institute, The Nature Conservancy, and the Cornell AtkinsonCenter for Sustainability) https://www.nature.org/en-us/what-we-do/ourinsights/reports/financing-nature-biodiversity-report/

114. Wilkinson, R. and Pickett, K. (2011). The Spirit Level: Why Greater Equality Makes Societies Stronger (Bloomsbury)

115. Otto, I., Kim, K. M., Dubrovsky, N. and Lucht, W. (2019). Shift the focus from the super-poor to the super-rich. Nature Clim Change 9, 82-87.

116. Islam, S. N. (2015). Inequality and Environmental Sustainability (United Nations Department of Economic and Social Affairs). https://www.oecd-ilibrary.org/docserver/6d0f0152en.pdf?expires $=1592964679 \& i d=i d \& a c c n a m e=$ guest $\&$ checksum $=D$ E64DC80C3AA3595602336BD0F54E75D

117. Tessum, C., Apte, J., Goodkind, A., Muller, N., Mullins, K., Paolella, D., Polasky, S., Springer, N., Thakrar, S., Marshall, J. et al. (2019). Inequity in consumption of goods and services adds to racial-ethnic disparities in air pollution exposure. PNAS 116 (13), 6001-6006.

118. Loft, L., Gehrig, S., Salk, C. and Rommel, J. (2020). Fair payments for effective environmental conservation. PNAS 117, 14094-14101.

119. Kashwan, P. (2017). Inequality, democracy, and the environment: A cross-national analysis. Ecol Econ 131, 139-151.

120. Illes, A., Kettunen, M., ten Brink, P., Santos, R., Droste, N. and Ring, I. (2017). Exploring the policy mix for biodiversity financing: opportunities provided by environmental fiscal instruments in the EU. In. The Green Market Transition: Carbon Taxes, Energy Subsidies and Smart Instrument Mixes. S. Weishaar, L. Kreiser, J. Milne, H. Ashiabor and M. Mehling, eds. (Edward Elgar), 261-276. 
121. Spangenberg, J., Omann, I., and Hinterberger, F. (2002).

Sustainable growth criteria: Minimum benchmarks and scenarios for employment and the environment. Ecol Econ 42, 429-443.

https://doi.org/10.1016/S0921-8009(02)00125-8

122. Neugebauer, S., Traverso, M., Scheumann, R, Chang, Y. J., Wolf, K., and Finkbeiner, M. (2014). Impact pathways to address social well-being and social justice in SLCA — fair wage and level of education. Sustain 6, 4839-4857.

123. Abraham, J. (2017). Just transitions for the miners: Labor environmentalism in the Ruhr and Appalachian Coalfields. New Pol Sci 39, 218-240.

124. McCauley, D. and Heffron, R. (2018). Just transition: Integrating climate, energy and environmental justice. Energy Policy 119, 1-7.

125. Stiglitz, J., Sen, A. and Fitoussi, J. P. (2009). Report of the Commission on the Measurement of Economic Performance and Social Progress (Commission on the Measurement of Economic Performance and Social Progress) http://files.harmonywithnatureun.org/uploads/upload112.pdf 126. Bleys, B. and Whitby, A. (2015). Barriers and opportunities for alternative measures of economic welfare. Ecol Econ 117, 162-172. 127. Talberth, T. and Weisdorf, M. (2017). Genuine Progress Indicator 2.0: Pilot accounts for the US, Maryland, and City of Baltimore 2012-2014. Ecol Econ 142, 1-11.

128. Leach, K., Grigg, A., O'Connor, B., Brown, C., Vause, J. Gheyssens, J., Weatherdon, L., Halle, M., Burgess, N. D., Fletcher, R. et al. (2019). A common framework of natural capital assets for use in public and private sector decision making. Ecosyst Serv 36, 100899

129. Vardon, M, Burnett, P. and Dovers, S. (2016). The accounting push and the policy pull: balancing environment and economic decisions. Ecol Econ 124, 145-152.

130. Hein, L., Bagstad, K., Obst, C., Edens, B., Schenau, S., Castillo, G., Soulard, F., Brown, C., Driver, A., Bordt, M., Steurer, A. et al. (2020). Progress in natural capital accounting for ecosystems. Science 367 (6577), 514-515.

131. Warnell, K., Russell, M., Rhodes, C., Bagstad, K., Olander, L.P., Nowak, D. J., Poudel, R., Glynn, P., Hass, J., Hirabayashi, S., Carter Ingram, J. et al. (2020). Testing ecosystem accounting in the 
United States: A case study for the Southeast. Ecosyst Serv 43, 101099

132. Loorbach, D., Frantzeskaki, N., and Avelino, F. (2017).

Sustainability transitions research: Transforming science and practice for societal change. Annu Rev Environ Resour 42, 599-626.

133. Wells, P., Abouarghoub, W., Pettit, S. and Beresford, A. (2020). A socio-technical transitions perspective for assessing future sustainability following the COVID-19 pandemic. Sustainability: Science, Practice and Policy 16, 29-36.

134. Evans, K. L., Ewen, J. G., Guillera-Arroita, G., Johnson, J. A., Penteriani, V., Ryan, S., Sollmann, R. and Gordon, I. (2020). Conservation in the maelstrom of Covid-19 - a call to action to solve the challenges, exploit opportunities and prepare for the next pandemic. Anim Conserv 23, 235-238.

135. Everard, M., Johnston, P., Santillo, D., and Staddon, C. (2020). The role of ecosystems in mitigation and management of Covid-19 and other zoonoses. Environ Sci Policy 111, 7-17.

136. Milkoreit, M., Hodbod, J., Baggio, J., Benessaiah, K., CalderónContreras, R., Donges, J., Mathias, J-D., Rocha, J. C., Schoon, M. and Werners, S. (2018). Defining tipping points for social-ecological systems scholarship-an interdisciplinary literature review. Env Res Letters 13, $033005 \mathrm{https}: / /$ doi.org/10.1088/1748-9326/aaaa75

137. Otto, I., Donges, J., Cremades, R., Bhowmik, A., Hewitt, R., Lucht, W., Rockström, J., Allerberger, F., McCaffrey, M., Doe, S. et al. (2020). Social tipping dynamics for stabilizing Earth's climate by 2050. PNAS 117 (5), 2354-2365.

https://doi.org/10.1073/pnas.1900577117

138. Kopp, R. E., Shwom, R. L., Wagner, G. and Yuan, J. (2016).

Tipping elements and climate-economic shocks: Pathways toward integrated assessment. Earth's Future 4, 346-372.

https://doi.org/10.1002/2016EF000362

139. Keiser, D. and Shapiro, J. (2019). Consequences of the Clean Water Act and the demand for water quality. Q J Econ 134, 349-396. https://doi.org/10.1093/qje/qjy019

140. Rinscheid, A. (2015). Crisis, policy discourse, and major policy change: Exploring the role of subsystem polarization in nuclear energy policymaking. Eur Policy Analysis 1, 34-70.

https://doi.org/10.18278/epa.1.2.3 
141. Birkland, T. (2006). Lessons of Disaster: Policy Change after Catastrophic Events (Georgetown University Press)

142. Tews, K., Busch, P. O. and Jörgens, H. (2003). The diffusion of new environmental policy instruments. Eur J Political Res 42, 569600. https://doi.org/10.1111/1475-6765.00096

143. Bentley, R., Maddison, E., Ranner, P., Bissell, J., Caiado, C., Bhatanacharoen, P., Clark, T., Botha, M., Akinbami, F., Hollow, M. et al. (2014). Social tipping points and Earth systems dynamics. Front. Environ. Sci. 2, 35. https://doi.org/10.3389/fenvs.2014.00035 144. Delmas, M., Lyon, T., and Maxwell, J. (2019). Understanding the role of the corporation in sustainability transitions. Organ Environ 32 (2), 87-97.

145. Galvin, R. and Healy, N. (2020). The Green New Deal in the United States: What it is and how to pay for it. Energy Res Soc Sci 67, 101529.

146. CDC Biodiversité (2020). Intégrer la Biodiversité dans la Relance Post-Covid: 35 Propositions (Group Caisse des Dépôts and Mission Économie de la Biodiversité) https://www.cdc-

biodiversite.fr/wp-content/uploads/2020/06/BIODIV-2050-N20-FR6PAGES-IMP-WEB-MD.pdf

147. OECD (2020). Building Back Better: A Sustainable, Resilient Recovery after COVID-19. (Organization for Economic Cooperation and Development) http://www.oecd.org/coronavirus/policyresponses/building-back-better-a-sustainable-resilient-recoveryafter-covid-19-52b869f5/

148. Bergquist, P., Mildenberger, M., and Stokes, L. (2020). Combining climate, economic, and social policy builds public support for climate action in the US. Environ. Res. Lett. 15, 054019

149. Secretariat of the Convention on Biological Diversity (2020). Global Biodiversity Outlook 5, https://www.cbd.int/gbo/gbo5/publication/gbo-5-en.pdf 